\title{
Sugarcane Mosaic Virus Resistance in the Wisconsin Sweet Corn Diversity Panel
}

\author{
Lillian Hislop, Elizabeth Stephanie, and Patrick Flannery \\ Department of Agronomy, College of Agricultural and Life Sciences, University of \\ Wisconsin-Madison, Madison, WI 53706
}

\begin{abstract}
Matheus Baseggio and Michael A. Gore
Plant Breeding and Genetics Section, School of Integrative Plant Science, Cornell University, Ithaca, NY 14853
\end{abstract}

\author{
William F. Tracy \\ Department of Agronomy, College of Agricultural and Life Sciences, University of \\ Wisconsin-Madison, Madison, WI 53706
}

\begin{abstract}
Additional INDEX words. genome-wide association, plant breeding, sweet maize, Zea mays
Abstract. Sugarcane mosaic virus [SCMV (Potyvirus sugarcane mosaic virus)] is an ssRNA virus that negatively affects yield in maize (Zea mays) worldwide. Resistance to SCMV is controlled primarily by a single dominant gene $(S c m 1)$. The goal of this study was to identify sweet corn (Z. mays) inbreds that demonstrate resistance to SCMV, confirm the presence of genomic regions previously identified in maize associated with resistance, and identify other resistant loci in sweet corn. Eight plants from each of 563 primarily sweet corn inbred lines were tested for SCMV resistance. Plants were inoculated $14 \mathrm{~d}$ after planting and observed for signs of infection $24 \mathrm{~d}$ after planting. A subset of 420 inbred lines were genotyped using 7504 high-quality genotyping-by-sequencing single-nucleotide polymorphism markers. Population structure of the panel was observed, and a genome-wide association study was conducted to identify loci associated with SCMV resistance. Forty-six of the inbreds were found to be resistant to SCMV $10 \mathrm{~d}$ after inoculation. The $S \mathrm{~cm} 1$ locus was confirmed with the presence of two significant loci on chromosome $6\left(P=2.5 \times 10^{-8}\right.$ and $1.6 \times 10^{-8}$ ), $5 \mathrm{Mb}$ downstream of the $S \mathrm{~cm} 1$ gene previously located at Chr6: 14194429.14198587 and the surrounding 2.7-Mb presence-absence variation. We did not identify other loci associated with resistance. This research has increased information on publicly available SCMV-resistant germplasm useful to future breeding projects and demonstrated that SCMV resistance in this sweet corn panel is driven by the $\operatorname{Scm} 1$ gene.
\end{abstract}

Sugarcane mosaic virus [SCMV (Potyvirus sugarcane mosaic virus)] has a worldwide geographic range and causes significant yield losses in maize [Zea mays (Kuntze et al., 1995; Shukla et al., 1989)]. SCMV causes an average of $10 \%$ to $15 \%$ yield loss in maize grown in China and is said to be the most important viral maize disease in Europe (Kuntze et al., 1997; Zhang et al., 2003). If plants are infected when young, SCMV can reduce ear weight, plant height, and total plant weight (Johnson et al., 1972; Kuntze et al., 1995). When SCMV coinfects with Machlomovirus maize chlorotic mottle virus, it can result in maize lethal necrosis disease (MLN), causing total yield loss (Wangai et al., 2012). SCMV is one of the positive-sense, single-strand RNA viruses found within the Potyviridae family, previously denoted as Maize dwarf mosaic virus- $B$ (Shukla et al., 1989). Other viruses within the Potyviridae include Potyvirus johnsongrass mosaic virus, and Potyvirus maize dwarf mosaic virus (Shukla et al., 1989, 1992). In addition to maize, SCMV also infects sugarcane (Saccharum sp.) and sorghum (Sorghum sp.), causing stunting and chlorosis (Kuntze et al., 1995; Shukla et al., 1989). The virus is transmitted by corn

Received for publication 11 June 2021. Accepted for publication 14 Sept. 2021. Published online 25 October 2021.

This article is based on research that is supported by the National Institute of Food and Agriculture (SCRI 2018-51181-28419) and the University of Wisconsin-Madison College of Agricultural and Life Sciences. Thank you to Tim Gustafson for providing pathogen inoculum and Gustafson and Natalia de Leon for review.

L.H. is the corresponding author. E-mail: 1mhislop@wisc.edu.

This is an open access article distributed under the CC BY-NC-ND license (https://creativecommons.org/licenses/by-nc-nd/4.0/). leaf aphids (Rhopalosiphum maidis) in a nonpersistent manner, and it is diagnosed with symptoms such as chlorosis, stunting, and reduced plant weight (Knoke et al., 1974). Chemical or agronomic control of aphids are not effective at eliminating transmission of SCMV (Charpentier, 1956). However, genetic resistance has proven to be an effective means of controlling SCMV (Liu et al., 2017; Xing et al., 2006). Genetic resistance is primarily linked with the $S \mathrm{~cm} 1$ gene within a large presence-absence variation (PAV) on chromosome 6 (Gustafson et al., 2018). Mosaic virus genetic resistance was transferred intentionally into sweet corn $(Z$. mays) as early as 1983 (Mikel et al., 1984).

The reaction to SCMV infection in field maize has been studied extensively. Kuntze et al. (1995) tested 124 European flint and dent maize inbreds for lasting resistance to SCMV under multiple conditions. Twenty-four inbreds showed resistance in both greenhouse and field conditions 4 weeks after inoculation. They also found only three inbreds completely resistant to SCMV 7 weeks after inoculation. Nineteen inbreds displayed delayed symptom expression (Kuntze et al., 1995). Subsequently, Kuntze et al. (1997) screened 122 European maize inbreds in greenhouse conditions and showed 34 inbreds had no symptoms 10 to $14 \mathrm{~d}$ after inoculation (DAI). A second experiment in field conditions found only three inbreds (D21, D32, and FAP1360A) that were completely resistant to SCMV and four inbreds (D06, D09, R2306, and FAP1396A) with partial resistance when evaluated 28 and 49 DAI (Kuntze et al., 1997).

Gustafson et al. (2018) evaluated SCMV resistance in field maize within the Wisconsin Diversity Panel under inoculated 
field conditions and found that 31 of the 578 inbreds tested were resistant to SCMV at 35 DAI. Gustafson et al. (2018) found that when inoculation was delayed from the three- to the six-leaf growth stage, symptom development was reduced, but inbreds that did not have the $S \mathrm{~cm} 1$ gene, due to the absence variant, were susceptible regardless of inoculation time points. In agreement, an earlier study found that younger plants are most susceptible to infection through inoculation, and that incidence of disease was halved when susceptible maize hybrids were inoculated at 11-leaf stage compared with five-leaf stage (Rosenkranz and Scott, 1978). Previous studies have determined that evaluation of SCMV resistance is not influenced significantly by testing in the field compared with greenhouse or by methods of manual inoculation, such as the rub method or the air-brush method (Kuntze et al., 1995).

Two loci conferring resistance to SCMV are known in maize, Scm1 and Scm 2 (or Scmv1 and Scmv2), on the short arm of chromosome 6 and the centromeric region of chromosome 3, respectively (Gustafson et al., 2018; McMullen and Louie, 1989; Melchinger et al., 1998; Simcox et al., 1995). Scm1 and Scm2 were first mapped in association with SCMV in 1989, and both were identified as dominant genes (McMullen and Louie, 1989). $\mathrm{Scm} 1$ is a dominant gene, conferring resistance to infection at all developmental stages, especially resistance in early stages of development (Dußle et al., 2000; Gustafson et al., 2018; Jones et al., 2007; Tao et al., 2013). Scm2 is associated with higher degree of resistance to SCMV infection in populations, especially at later stages of development and behaves epistatically with Scml (Dußle et al., 2000; Xing et al., 2006). Scml is located at Chr6: 14194429.14198587 in B73 v3 and is within a 2.7-Mb PAV spanning from 12.9 to $15.4 \mathrm{Mb}$. Gustafson et al. (2018), showed that all susceptible lines with the absence variant were found to be susceptible to SCMV and had an allele associated with susceptibility downstream at $19.4 \mathrm{Mb}$, due to the inability of making associations with missing single-nucleotide polymorphisms (SNPs). Liu et al. (2017) determined the casual gene at $\mathrm{Scm} 1$ to be Zmtrxh which encodes an atypical h-type thioredoxin and suppresses viral RNA accumulation in the cytoplasm. Scm 2 is partially dominant for resistance to SCMV but often does not appear in association with resistance at early time points (Xia et al., 1999). Minor quantitative trait loci (QTL) have also been identified on chromosomes $1,3,5$, and 10 that explain $6 \%$ to $10 \%$ of phenotypic variance in total (Gustafson et al., 2018; Melchinger et al., 1998; Xia et al., 1999).

Genome-wide association studies (GWAS) are frequently used in maize research to detect associations of genetic markers with traits of interest (Xiao et al., 2017). GWAS can identify associated loci with high resolution by using diverse populations that have undergone many generations of recombination, leading to a more rapid decay of linkage disequilibrium (LD; Flint-Garcia et al., 2003). Association mapping panels combined with GWAS have been used to gain insights on the genetic architecture of MLN and have found 24 SNPs associated with MLN resistance linked to 20 putative candidate genes that can potentially be used in MLN resistance breeding programs (Gowda et al., 2015). Although GWAS identifies associated loci and candidate genes, follow-up is often required to directly connect those loci with causal genes, making it useful predictively in many cases but not always immediately applicable (Broekema et al., 2020; Pierce et al., 2020). Additionally, GWAS has trouble identifying rare alleles or alleles that are highly fixed in the population (Hamazaki et al., 2020). Three GWAS have been done previously on the Wisconsin Sweet Corn Diversity Panel (WSCDP), investigating loci associated with tocochromanols, carotenoid, and elemental variation in fresh sweet corn kernels. These studies suggest that GWAS are effective in the WSCDP (Baseggio et al., 2019, 2020, 2021).

The objectives of this study were to identify sweet corn inbreds with genetic resistance to SCMV, confirm the presence of genomic regions previously identified in field maize associated with resistance (the $S \mathrm{~cm} 1$ and $S \mathrm{~cm} 2$ loci), and determine if there were other putative resistance loci unique to the sweet corn panel.

\section{Materials and Methods}

GermplasM. In 2019, 563 sweet corn inbreds from the WSCDP were evaluated for resistance to SCMV under greenhouse conditions (Supplemental Table 1). These inbreds were part of the WSCDP, a diversity panel designed to evaluate the genetic architecture and breadth of molecular and phenotypic diversity within public, temperate, sweet corn germplasm. The WSCDP has 581 inbreds in the full panel, through the size and composition of the inbreds used in WSCDP experiments depending on the experiment's focus, germplasm availability, and resources (Baseggio et al., 2019, 2020, 2021). The pedigrees of many of the inbreds within the panel are known through internal records. Inbreds found to be SCMV-resistant had their pedigree traced for obvious inherited sources of genetic resistance. A large portion of the lines within the WSCDP are sourced from the University of Illinois-Urbana and University of WisconsinMadison sweet corn breeding programs (330 of the 563 in this study), due to availability and the extent of modern sweet corn germplasm derived from those programs.

Phenotypic evaluation. The experiment was conducted at the University of Wisconsin-Madison Walnut Street Greenhouses (Madison). The greenhouse was kept at 24 to $28^{\circ} \mathrm{C}$ during the day and $18^{\circ} \mathrm{C}$ at night. Lighting was supplied by $400-\mathrm{W}$ high-pressure sodium lights, four lights over each bench of 60 pots. Lights remained on for $16 \mathrm{~h} \cdot \mathrm{d}^{-1}$ or until $400 \mu \mathrm{mol}$ of natural light was reached. One hundred twenty inbreds were planted at a time in sets of 60 pots per bench and with the inbred's planting order determined at random. Eight kernels of each inbred were planted in 19.7-cm-diameter pots about $2 \mathrm{~cm}$ deep in media composed of $65 \%$ to $75 \%$ sphagnum peatmoss and $8 \%$ to $35 \%$ perlite (ProMix HP, Premier Tech Horticulture, Quakertown, PA). Plants were fertilized three times per week with $20 \mathrm{~N}-4.4 \mathrm{P}-16.6 \mathrm{~K}$ fertilizer (Peters Professional 20-10-20 Peat Lite Special Fertilizer; ICL Specialty Fertilizers, Summerville, SC).

Seedlings were inoculated $14 \mathrm{~d}$ after planting (DAP), when all inbreds were around the three-leaf stage to maximize susceptibility (Rosenkranz and Scott, 1978). The SCMV isolate used for inoculation was collected in 1996 from a Wisconsin sweet corn field. The amplified isolate was confirmed to be a SCMV isolate via RNA sequencing analysis and enzyme-linked immunoassay (Agdia, Elkhart, IN) and tested negative for Maize dwarf mosaic virus, Wheat mosaic virus, and Wheat streak mosaic virus (Gustafson et al., 2018). SCMV inoculum was maintained on a susceptible sweet corn hybrid, GH4927 (Syngenta, Basel, Switzerland), under isolated greenhouse conditions. A cycle of available inoculum was maintained by inoculating uninfected GH4927 14 DAP and planting new GH4927 every $14 \mathrm{~d}$. Inoculum was prepared by grinding six to 10 leaves of the 21 -d-old infected hybrid, with $\approx 250 \mathrm{~mL}$ of 
municipal water and $5 \mathrm{~g}$ of carborundum using a mortar and pestle. Inoculation was done mechanically with the carborundum creating injury points by dipping a gloved hand in the inoculum and running the seedlings' leaves through pinched fingers, known as the rubinoculation method (Knoke et al., 1974). Stand count was recorded for each pot on the same day as inoculation. Inbreds with zero germination were dropped from the study.

Symptoms were visually scored $10 \mathrm{DAI}$, and the number of plants per pot displaying any symptoms were recorded. Diagnostic symptoms were mosaic chlorosis on leaves with contrasting green on a background of paler green or yellow chlorotic areas, occasionally with streaks or stripes (Fuchs and Grüntzig, 1995). Uninfected plants did not show signs of chlorosis or mosaic patterning. To eliminate the possibility of false resistance ratings due to mistakenly uninoculated pots, inbreds that displayed no symptoms on any seedlings were tested again with three additional pots of eight kernels each planted all within the same round. Four control pots of GH4927 were included at random on each bench of 60 pots. The control pots were inoculated and served as a check for inoculation effectiveness. Each seedling was either rated as symptomatic or asymptomatic regardless of intensity of symptoms. Each pot of eight kernels was considered an experimental unit. The percentage of symptomatic plants for each inbred was calculated by dividing the total number of symptomatic seedlings by the total number of seedlings grown across all replicates. Inbreds with no symptomatic plants 10 DAI within their first planting and no symptomatic plants 10 DAI in their three follow-up replicates were labeled as resistant to SCMV. The rates of germination and symptomatic plants were evaluated for the susceptible control and for the panel at large. Correlation between rates of symptomatic plants and planting order or bench position were assessed, and no correlation was found.

GENOTYPING. In 2013, samples from each inbred in the WSCDP were taken and sequenced at the Cornell Biotechnology Resource Center (Ithaca, NY) using genotyping-by-sequencing (GBS) as described previously (Baseggio et al., 2019; Elshire et al., 2011). The sequence data used in this study has been archived in the National Center of Biotechnology Information (Bethesda, MD) BioProject under accession number PRJNA482446 and in the Sequence Read Archives under accession SRP154923. The raw GBS sequence data consisted of 955,690 SNPs called using the default parameters in the TASSEL 5 GBSv1 production pipeline (Bradbury et al., 2007) with the ZeaGBSv2.7 Production TagsOnPhysicalMap file in B73 RefGen_v2 coordinates (Panzea, Ithaca, NY). The SNP genotype calls from this study were combined with the raw sequencing data of inbreds included in this screening within the genotyping study of the U.S. Department of Agriculture, Agriculture Research Service, North Central Regional Plant Introduction Station collection in Ames, IA (Romay et al., 2013). The raw SNP genotype calls from the combined set were filtered to retain only biallelic SNPs with greater than $10 \%$ call rate. This raw combined sequencing dataset has been used previously in several studies when analyzing the WSCDP for other traits (Baseggio et al., 2019, 2020, 2021). Markers were further filtered by removing SNPs with minor allele frequency of less than 5\%, and SNPs with call rates of less than $90 \%$ - percentage of SNPs successfully genotyped for each inbred - within TASSEL and were pruned for LD at a rate of 0.98 or higher within SNPRelate (Bradbury et al., 2007; Zheng et al., 2012). The result was a set of 7504 non-imputed highquality marker sites for 420 of the inbreds tested. Previous studies involving the WSCDP used the same GBS data, filtered differently and imputed (Baseggio et al., 2019, 2020, 2021). We avoided imputation and worked with the raw sequencing data to ensure PAVs were maintained correctly.

Association mapPing. This study's GWAS was conducted on these markers using the general $\mathrm{P}+\mathrm{K}$ mixed model through the genetic analysis R package GWASpoly (Rosyara et al., 2016) with three principal components and the kinship matrix calculated by the realized relationship matrix based on VanRaden's method (VanRaden, 2008). The GWAS was run using a general model, meaning all heterozygotes have the same effect and there is no weighting based on allelic dosage. GWAS was run on the 420 inbreds with GBS data. One hundred forty-three inbred lines did not have associated genetic information because sequencing was conducted before the SCMV screening. These lines were screened despite the lack of sequencing data for the purpose of identifying their SCMV resistance status for the benefit of sweet corn breeding programs.

We estimated the presence of $\mathrm{Scml}$ in the inbreds by comparing their haplotype near the Scml locus to IL793a, an inbred with known $S \mathrm{~cm} 1$ presence in its pedigree and $0 \%$ symptomatic plants in this screening. We will refer to this haplotype as the Scm 1- IL793a haplotype. The Scm 1- IL793a haplotype was classified by three loci: the locus at $19.9 \mathrm{Mb}$ which was associated with resistance during the initial GWAS that was closest to the $\mathrm{Scm} 1$ gene and two SNPs nearest that 19.9-Mb locus. The locus at $19.9 \mathrm{Mb}$ was chosen as the basis for the haplotype due to a lack of SNP coverage in the PAV where Scml is located. A closer haplotype could not be used to infer Scm 1 presence because there was only one SNP within the PAV sequenced, and it was not enough of a high-quality locus to be included within our filtering parameters. Due to the commonality of the absence variation within the diversity panel, the PAV was not able to be captured by our GBS technique. Previous studies used a similar associated locus at $19.4 \mathrm{Mb}$ to infer $\mathrm{Scm} 1$ presence (Gustafson et al., 2018). A simple $t$ test of the percentage of symptomatic plants was conducted between the inbreds with and without the Scm 1- IL793a haplotype. We also conducted GWAS on the subset of 360 inbreds that did not have the Scm1- IL 793a haplotype. Population structure analysis and visualization in the form of principal component analysis (PCA) was conducted with TASSEL (Bradbury et al., 2007), and R packages SNPRelate (Zheng et al., 2012) on the 420 inbred group. Population structure analysis was done specifically for this study due to our unique filtering parameters.

Associated GENE DISCOVERY. Linkage disequilibrium decay was calculated using a full matrix comparison in TASSEL and visualized in R (Bradbury et al., 2007). We used the same filtering as described earlier, without LD pruning for a total of 12,012 marker sites to calculate the genome-wide LD within the 420 inbreds genetically analyzed. The LD decay was used to inform our candidate gene window of $250 \mathrm{~kb}$. The loci of interest that scored above the 5\% Bonferroni threshold were deemed significant, and gene models within a $250-\mathrm{kb}$ window of the loci's flanking region were recorded as associated genes. The Maize B73 RefGen_v3 genome assembly was consulted for associated genes through MaizeGDB (Portwood et al., 2019).

\section{Results}

VARIATION IN RESISTANCE. Germination among the screened inbreds was strong with $96 \%$ of inbreds germinating three or more seedlings, the median stand count being seven seedlings 

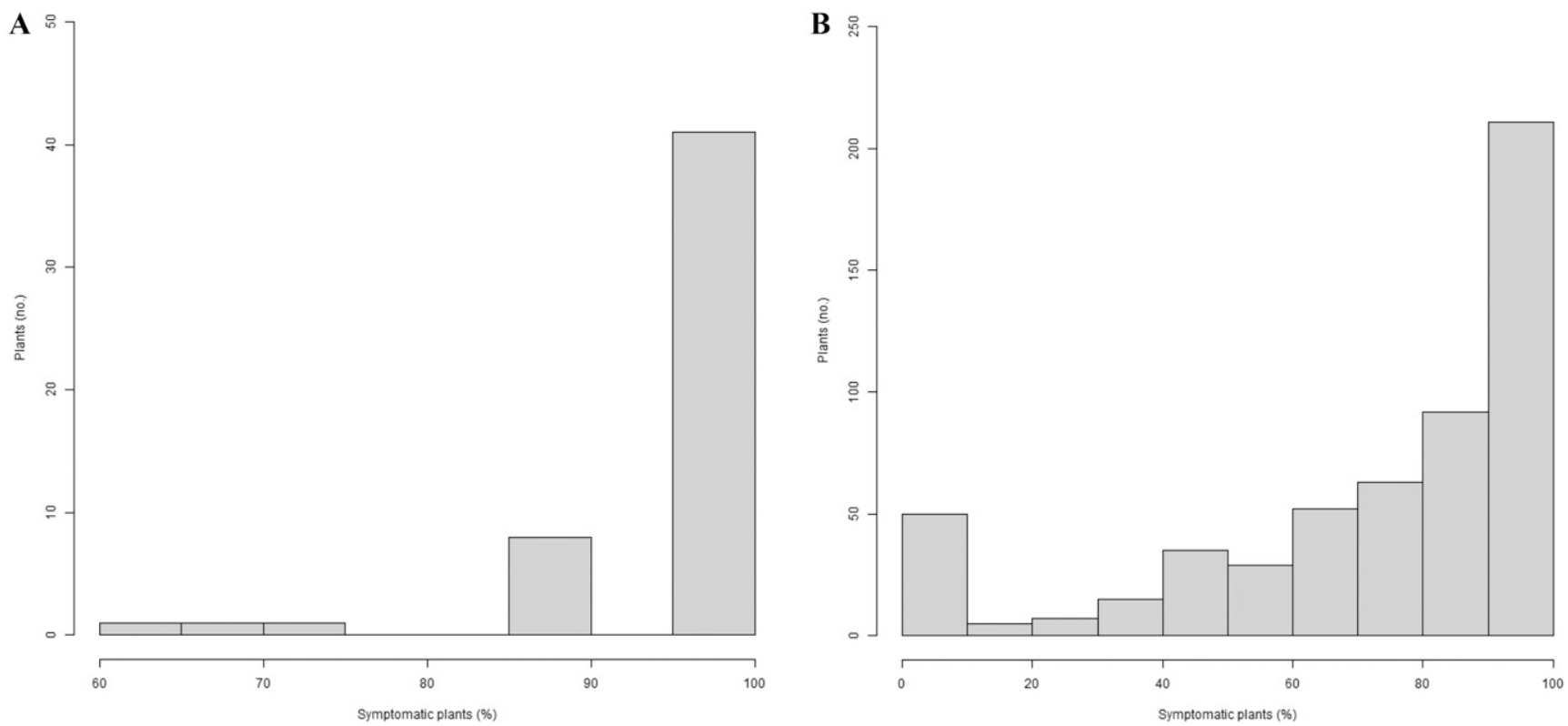

Fig. 1. Number of percent symptomatic inbred sweet corn plants among (A) the susceptible controls and (B) all screened inbreds.

from eight planted kernels, and the mean being 6.6 seedlings. Ninety-six percent of the control plants (Syngenta GH4927), which has the scm 1 allele, were symptomatic and $21 \%$ of the control pots had one or more asymptomatic plants (Fig. 1A). Given that $S \mathrm{~cm} 1$ confers a dominant form of resistance, asymptomatic plants among the controls are likely due to inoculation escapes or minor seed lot impurity.

Among the 563 inbreds tested, 559 germinated adequately for screening. From those 559 inbreds, at 10 DAI, 46 inbreds had $0 \%$ symptomatic plants. Forty-eight inbreds had fewer than $10 \%$ symptomatic plants at 10 DAI. Notably, C.I.540 was included and screened twice, and was rated as $0 \%$ and $6.7 \%$ symptomatic in the two screenings. Sixty-two inbreds had between $10 \%$ and $\leq 50 \%$ plants showing symptoms (Supplemental Table 1). Two



hundred and thirty-six inbreds had between 50\% and 90\% plants with symptoms and 211 inbreds were $>90 \%$ symptomatic (Fig. 1B).

Of the 46 inbreds that were classified as resistant to SCMV, 33 inbreds had associated GBS data. Within our sequenced panel, 60 inbreds were found with the Scm 1- IL793a haplotype and 360 without. Our $t$ test between the inbreds with and without the Scm 1- IL793a haplotype found that the groups had significantly different percent symptoms $\left[t=5.0, P=4.6 \times 10^{-6}\right.$ (Fig. 2)]. The group with the Scm1- IL793a haplotype had a mean symptomatic plant percentage of $50 \%$ and the group without had a mean percentage of $77 \%$. Twenty-one of the 60 inbreds with the Scm1- IL793a haplotype had no plants that showed symptoms and were therefore classified as resistant.



Fig. 2. Number of percent symptomatic inbred sweet corn plants among the screened inbreds (A) with the Scm1- IL793a associated haplotype and (B) without the Scm 1- IL793a associated haplotype. 


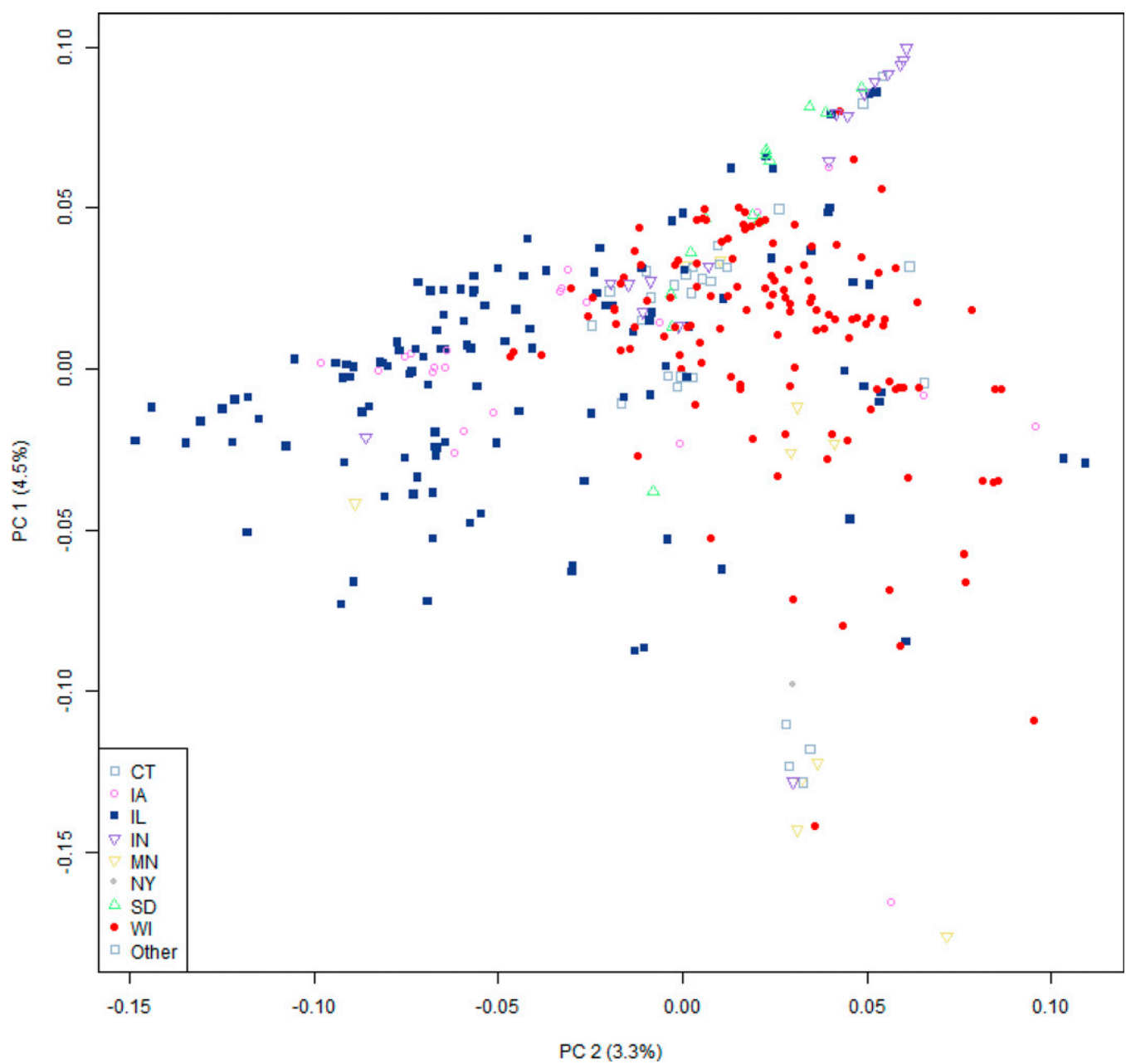

Fig. 3. Principal component (PC) analysis of 420 sweet corn inbreds within the Wisconsin Sweet Corn Diversity Panel, labeled with their program of origin: CT = University of Connecticut-Storrs; IA = Iowa State University-Ames; IL = University of Illinois-Urbana/Champaign (Champaign, IL); IN = Purdue University (West Lafayette, IN); MN = University of Minnesota-Twin Cities (Minneapolis, MN); SD = South Dakota State University (Brookings, SD); WI = University of Wisconsin-Madison; Other = all other programs within the panel.

GWAS detected loci. Previous studies have also found loci as far away as $5 \mathrm{Mb}$ downstream of the $2.7-\mathrm{Mb}$ PAV on chromosome 6 to be in strong LD with the PAV (Gustafson et al., 2018).

Association anAlysis. Genome-wide association was conducted using 420 inbreds scored with SNP markers. Through the R package GWASpoly, loci of interest using the general model were identified as SNP marker S6_19987285 and S6_36947510 on chromosome 6 at position and $36,947,510$ all above the Bonferroni threshold of 5.13 $-\log _{10}(\mathrm{P})\left[P=2.5 \times 10^{-8}\right.$ and $1.6 \times 10^{-8}$ (Fig. 5)]. These loci are downstream of the PAV spanning from 12.9 to 15.4 Mb. No SNPs within the PAV were present after filtering due to the prevalence of the absence variation in the panel. Due to the rate of LD decay within these samples, a 250-kb window surrounding the two loci was used to identify nearby associated genes (Supplemental Fig. 1). Thirty-one associated gene models were found (Supplemental Tables 2 and 3). Due to the nature of the nearby PAV and previous research on downstream loci being linked with the PAV and causal genes within it, these

Population STRucture. Population structure was observed among the 420 sequenced inbreds (Fig. 3). Inbreds developed by the University of Illinois-Urbana/Champaign program are visibly distinct from the inbreds developed by the University of Wisconsin-Madison Sweet Corn Breeding Program, especially along the principal component two axis. The distinction between the Illinois and Wisconsin inbreds is also reflected in the PCA when labeled by endosperm type, indicating that Wisconsin and Illinois breeding programs have focused on breeding for different endosperm mutants (Fig. 4). Variance explained by the first principal component is equal to $4.5 \%$, and the variance explained by the second principal component equaled $3.3 \%$. Many of the resistant inbreds share similar ancestry as indicated by the pedigree analysis (Table 1 ).

LINKAGE DISEQUILIBRIUM. Within the WSCDP, we found that the median (50th percentile) of the 12,012 pre-LD-pruned highquality SNP markers showed LD decay to $R^{2}<0.1$ levels by $\approx 1$ $\mathrm{kb}$. However, there were large variances in the structure of LD and LD persisted at higher percentile cutoffs. Ninety percent of the SNPs reached $R^{2}<0.2$ levels by $\approx 250 \mathrm{~kb}$. Given this, candidate genes were included within $\mathrm{a} \pm 250 \mathrm{~kb}$ window of the genes are associated with the significant loci but are not necessarily candidate genes (Gustafson et al., 2018).

A second GWAS was conducted on only the 360 inbreds without the Scm1 haplotype within the WSCDP for the symptomatic percentage trait. No significant loci were found (Fig. 6).

\section{Discussion}

Phenotypic analysis. We found 46 inbreds (or 8.2\% of the panel) that qualified as resistant to SCMV, meaning totally asymptomatic 10 DAI with SCMV across four pot replications. Samples were inoculated at 14 DAP because younger plants are most susceptible to infection through inoculation (Rosenkranz and Scott, 1978). Many of the resistant inbreds had SCMV-resistance inbred parentage, according to their known pedigrees. Resistance to SCMV is an economically useful trait that has been bred into sweet corn inbreds, so it is unsurprising to find inbreds with known SCMV-resistant parents. However, there were several resistant inbreds such as We02412 and BST4 whose backgrounds reveal no known source of resistance. Of the susceptible inbreds, 509 inbreds were $>10 \%$ symptomatic, 


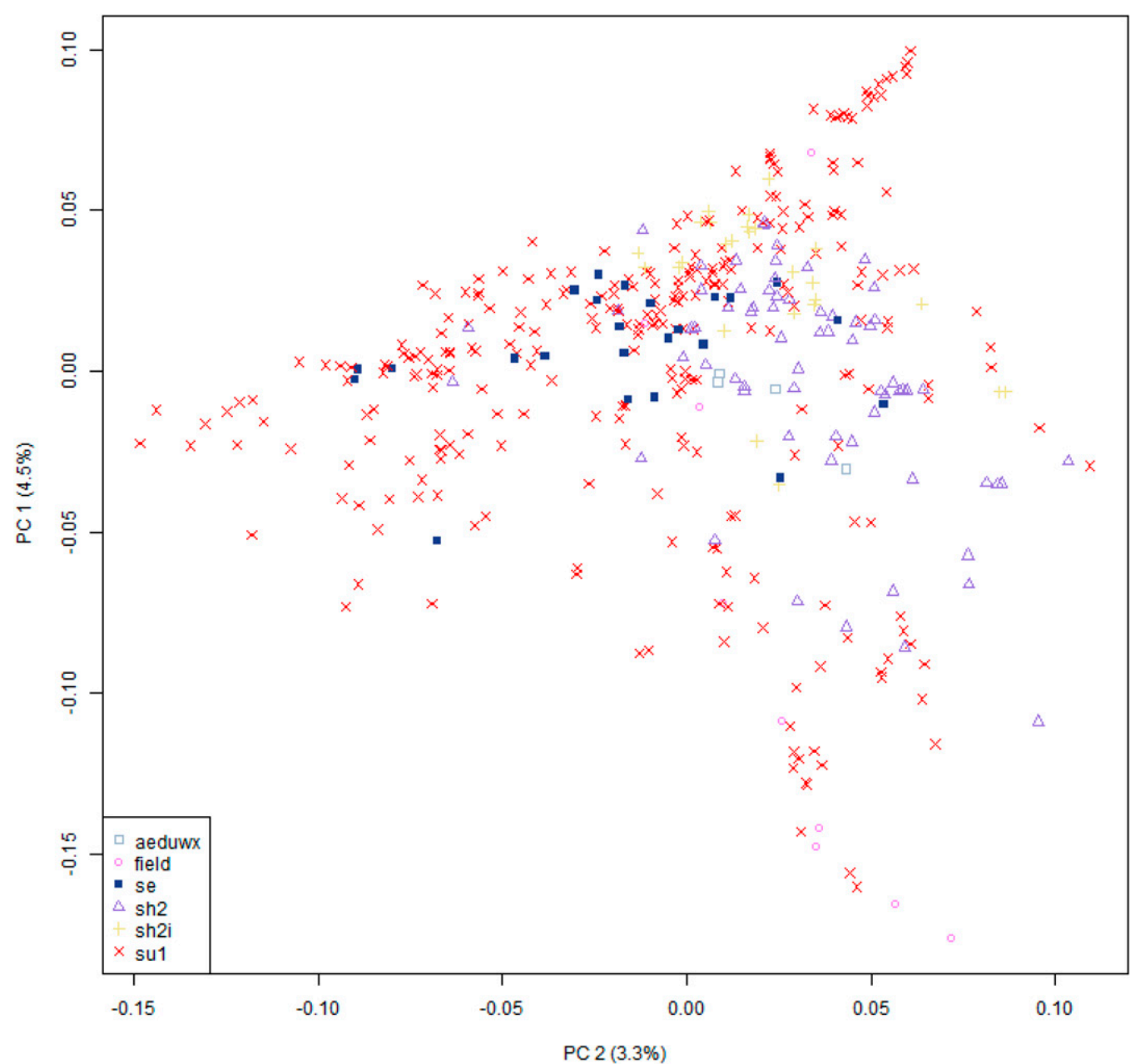

Fig. 4. Principal component (PC) analysis of 420 sweet corn inbreds within the Wisconsin Sweet Corn Diversity Panel. Inbreds are labeled with their endosperm mutants' categorization. aeduwx = amylose-extender: dull: waxy; se = sugary enhancer; sh2 = shrunken $2 ; \operatorname{sh} 2 \mathrm{i}=$ shrunken 2 intermediate; su $1=$ sugary 1 .

meaning that among all the plants of each inbred, $10 \%$ or more of their plants showed symptoms of SCMV infection. Inbreds B73 and C.I.540 were 3\% and 7\% symptomatic, respectively. Each inbred had no symptomatic seedlings during the first planting. B73 has two symptomatic seedlings out of the 23 plants that germinated during the second planting. Inbred C.I.540 had one symptomatic seedling out of 22 during the second planting. C.I.540 was screened twice, with the other screening fully resistant with $0 \%$ symptomatic plants. C.I.540 and B73 were found to have the Scm1- IL793a haplotype. The implied partial resistance does not follow with how SCMV acts in most other inbreds, and the one or two symptomatic plants are more likely due to outcrosses or admixtures in the seed source than due to partial susceptibility. Ninety-six percent of control plants were symptomatic, indicating that our infection methods were effective, and inbreds with $0 \%$ symptomatic plants were not resistant due to inoculating error. Notably, however, $21 \%$ of the control pots had one or more asymptomatic plants. The asymptomatic plants among the controls were likely due to inoculation error, pollen contamination, or admixture. This indicated that some of the inbreds that had between $50 \%$ and $90 \%$ symptomatic plants might have had less than $100 \%$ symptomatic plants due to inoculation error or a contaminated seed source as opposed to partial susceptibility. Among the 420 inbreds that had associated GBS information, we were able to identify which inbreds had the Scm1- IL793a haplotype. The average percent symptomatic plants were significantly different between the group with the ScmlIL793a haplotype and the group without the haplotype, indicating that the presence of the $S \mathrm{~cm}$ I- IL793a haplotype is associated with more resistant inbreds. However, we expected the number of resistant inbreds with ScmlIL793a haplotype to be higher, considering that seven inbreds without the ScmlIL793a haplotype were resistant. One explanation may be that because we did not have GBS data within the PAV of those seven inbreds, they do have the $S \mathrm{~cm} 1$ allele, but it is at linkage equilibrium with the Scm 1- IL 793a haplotype.

POPUlation STRUCTURE. There were clear signs of population structure within the WSCDP. Within the PCA, the inbreds clustered within the different breeding programs of origin with distinction among inbreds created by the University of Illinois-Urbana/Champaign and the University of Wisconsin-Madison (Fig. 3). As previously mentioned, these distinctions correlate with the endosperm mutant types, indicating that Wisconsin and Illinois breeding programs have focused on breeding for different endosperm mutants resulting in consistent differences in the genetics of their germplasm and visible population structure (Fig. 4). The clustering within the PCA indicates that many of the resistant inbreds are closely related as indicated by the pedigrees (Table 1).

Candidate Gene Discovery. Most of the SNPs used within the population in this analysis exhibited rapid linkage decay at most loci, likely due to the relatively few markers used within this study $\left(R^{2}<0.1\right.$ levels by $\left.\approx 1 \mathrm{~kb}\right)$. We found variation in the LD decay rates in different regions and chromosomes. Ninety percent of SNPs were at $R^{2}$ of about $0.1 \times 1 \mathrm{Mb}$, or $R^{2}<0.2 \times$ $250 \mathrm{~kb}$, which, in addition to the precedent of previous WSCDP studies, led us to select a $250-\mathrm{kb}$ window for finding associated genes (Baseggio et al., 2019). There were several gene models within the $250-\mathrm{kb}$ window surrounding the two associated-withresistance loci found in the GWAS study (Supplemental Tables 2 and 3). It is possible that these nearby genes could be used as markers in future studies. However, numerous previous studies confirm the importance of the $\mathrm{Scm} 1$ gene in conferring maize SCMV resistance (Dußle et al., 2000, 2003; Xu et al., 2000; 
Table 1 . The 46 identified resistant sweet corn inbreds, with any known resistant ancestors, notation of whether the inbred has associated genotyping-by-sequencing (GBS) data, and the inbreds' endosperm mutant type.

\begin{tabular}{|c|c|c|c|}
\hline $\begin{array}{l}\text { Resistant } \\
\text { inbred }\end{array}$ & $\begin{array}{l}\text { Known resistant } \\
\text { ancestor }\end{array}$ & $\begin{array}{l}\text { Associated } \\
\text { GBS data }\end{array}$ & $\begin{array}{c}\text { Endosperm } \\
\text { type }^{z}\end{array}$ \\
\hline 2 & & Yes & sul \\
\hline $83610 b$ & & Yes & sul \\
\hline $83612 b$ & & Yes & sul \\
\hline A632 & & Yes & Field \\
\hline $\mathrm{A} 632 \mathrm{su} / \mathrm{su}$ & A632 & & sul \\
\hline AS11 & $\mathrm{Pa} 405$ & Yes & sul \\
\hline BSQ1 & $\begin{array}{l}\text { B68 } \times \text { Silver } \\
\text { Queen }\end{array}$ & & sul \\
\hline BST1 & & & sul \\
\hline BST2 & & & sul \\
\hline BST4 & & & sul \\
\hline C.I.540 & & Yes & Field \\
\hline IL696a & & Yes & se \\
\hline IL793a & $\mathrm{Pa} 405$ & Yes & sul \\
\hline IL 794a & $\mathrm{Pa} 405$ & Yes & sul \\
\hline IL795a & $\mathrm{Pa} 405$ & Yes & sul \\
\hline IL 797a & & Yes & sul \\
\hline IL 799b & $\mathrm{Pa} 405$ & Yes & sul \\
\hline IL800a & $\mathrm{Pa} 405$ & & sul \\
\hline ILB5870 & & Yes & sul \\
\hline ILB6011 & $\mathrm{Pa} 405$ & Yes & sul \\
\hline Ma83608 & & Yes & sul \\
\hline MDM-15 & B68 & Yes & sul \\
\hline MDM-16 & B68 & Yes & sul \\
\hline MDM-17 & B68 & Yes & sul \\
\hline MDM-18 & B68 & Yes & sul \\
\hline MDM-20 & B68 & Yes & sul \\
\hline MDM3 & B68 & & sul \\
\hline MDM-5 & B68 & Yes & sul \\
\hline MDM-6 & B68 & Yes & sul \\
\hline NY MDM-1 & B68 & Yes & sul \\
\hline $\mathrm{OH} 7 \mathrm{~B}$ & & Yes & Field \\
\hline $\mathrm{T} 62 \mathrm{~s}$ & & Yes & sul \\
\hline We02412 & & Yes & se \\
\hline Wh10140R & & Yes & $\operatorname{sh} 2$ \\
\hline Wh10173V & Mexican Dent & Yes & $\operatorname{sh} 2$ \\
\hline Wh10216V & Mexican Dent & Yes & $\operatorname{sh} 2$ \\
\hline Wh10231V & Hawaiian SS & Yes & $\operatorname{sh} 2$ \\
\hline Wh11005 & Wh92047 & & $\operatorname{sh} 2$ \\
\hline Wh12014 & Wh92047 & & $\operatorname{sh} 2$ \\
\hline Wh12048V & Wh92047 & & $\operatorname{sh} 2$ \\
\hline Wh13022A & & & $\operatorname{sh} 2$ \\
\hline Wh13063A & Wh92047 & & $\operatorname{sh} 2$ \\
\hline Wh13070 & Wh92047 & & $\operatorname{sh} 2$ \\
\hline Wh13074 & Wh92047 & & $\operatorname{sh} 2$ \\
\hline Wh92047 & A632 & Yes & $\operatorname{sh} 2$ \\
\hline Wuh07469i & & & $\operatorname{sh} 2 i$ \\
\hline
\end{tabular}

${ }^{\mathrm{z} E n d o s p e r m}$ mutants types are $\mathrm{se}=$ sugary enhancer; $\mathrm{sh} 2=$ shrunken $2 ; \operatorname{sh} 2 \mathrm{i}=$ shrunken 2 intermediate; su $1=$ sugary 1 .

Yuan et al., 2003). Additionally, the two identified SNP markers S6_19987285 and S6_36947510 are relatively near the PAV surrounding the $S \mathrm{~cm} 1$ gene. Given these two factors, we believe that these associated loci are in LD with the $\mathrm{Scm} 1$ gene but not themselves indicative of other causal genes that are contributing to SCMV resistance. Note that the two significant loci are not within the $250-\mathrm{kb}$ LD window of $\mathrm{Scm} 1$ nor within the PAV that encompasses $\mathrm{Scm} 1$. Previous studies have found that an associated locus at $19.4 \mathrm{Mb}$ was in $\mathrm{LD}$ with the PAV, so we believe this is the case with our locus at $19.9 \mathrm{Mb}$ as well (Gustafson et al., 2018). We did not find any associated loci closer to the Scm 1, likely due to the lack of SNP coverage within the PAV spanning from 12.9 to $15.4 \mathrm{Mb}$. There were no SNPs from our GBS included within the 9.5- to $17.0-\mathrm{Mb}$ positions on chromosome 6 as the commonality of the absence variation made that region difficult to genotype. Numerous studies have shown $\mathrm{Scml}$ is a dominant allele, vital to SCMV resistance in maize (Dußle et al., 2000; Melchinger et al., 1998; Użarowska et al., 2009; Xia et al., 1999; Xing et al., 2006). Finding that Scml is present within the resistant inbreds in the WSCDP and that it contributes to resistance corroborates those previous studies.

We did not detect SNP markers associated with $\mathrm{Scm} 2$ in any of the GWAS, despite its documented effects (Dußle et al., 2000, 2003; Xu et al., 2000; Yuan et al., 2003). Even when controlling for the presence of $S \mathrm{~cm} 1$ by only analyzing those inbreds that do not have the Scml- IL793a haplotype, association between loci near $S \mathrm{~cm} 2$ and resistance was still not seen. This is likely because we only analyzed at one time point very early in development and $\mathrm{Scm} 2$ is associated with sustained resistance over maize's development (Dußle et al., 2000; Xing et al., 2006). Alternatively, this may be due to $S \mathrm{~cm} 2$ acting as a modifier to $\mathrm{Scm} 1$ and would only be detectable in a panel enriched for the $S \mathrm{~cm} 1$ presence (Użarowska et al., 2009).

Because this was the first screening of sweet corn inbreds for SCMV resistance, this study had shortcomings that could be improved with future research. Planting more replicates of each inbred in a completely randomized design could increase the power of the analysis and increase confidence in percentage of symptomatic plants. The lack of SNP coverage within the PAV containing $S \mathrm{~cm} 1$ was a study hinderance. Future studies should take special care to ensure SNP coverage of these area for more confidence in their categorization of inbreds having or not having the $\mathrm{Scml}$ gene. Additionally, higher SNP coverage overall would increase the likelihood of finding other genomic regions contributing to SCMV resistance. Finally, inoculating the inbreds at multiple time points and enriching the panel for inbreds with the $S \mathrm{~cm} 1$ gene could lead to identifying association with $S \mathrm{~cm} 2$ and resistance.

\section{Conclusions}

The purpose of this disease screening was to identify and study resistance to SCMV within temperate sweet corn. We used the WSCDP as a representative sample of the diversity found within sweet corn populations. We identified 46 inbreds that were fully resistant to SCMV when evaluated 10 DAI. Many of the inbreds we identified are publicly available and could be used by breeders interested in introducing SCMV resistance into their breeding programs. The role of $S \mathrm{~cm} 1$ was confirmed within sweet corn, but we did not detect the effects of $\mathrm{Scm} 2$ or of any novel loci associated with resistance. Future studies to investigate $\mathrm{Scm} 2$ contributions to resistance may use the WSCDP to screen the panel at multiple time points to better measure SCMV response over time. Additionally, targeted genotyping of the resistant lines within the panel would provide better discernment between resistant lines with the $S \mathrm{~cm} l$ gene. 


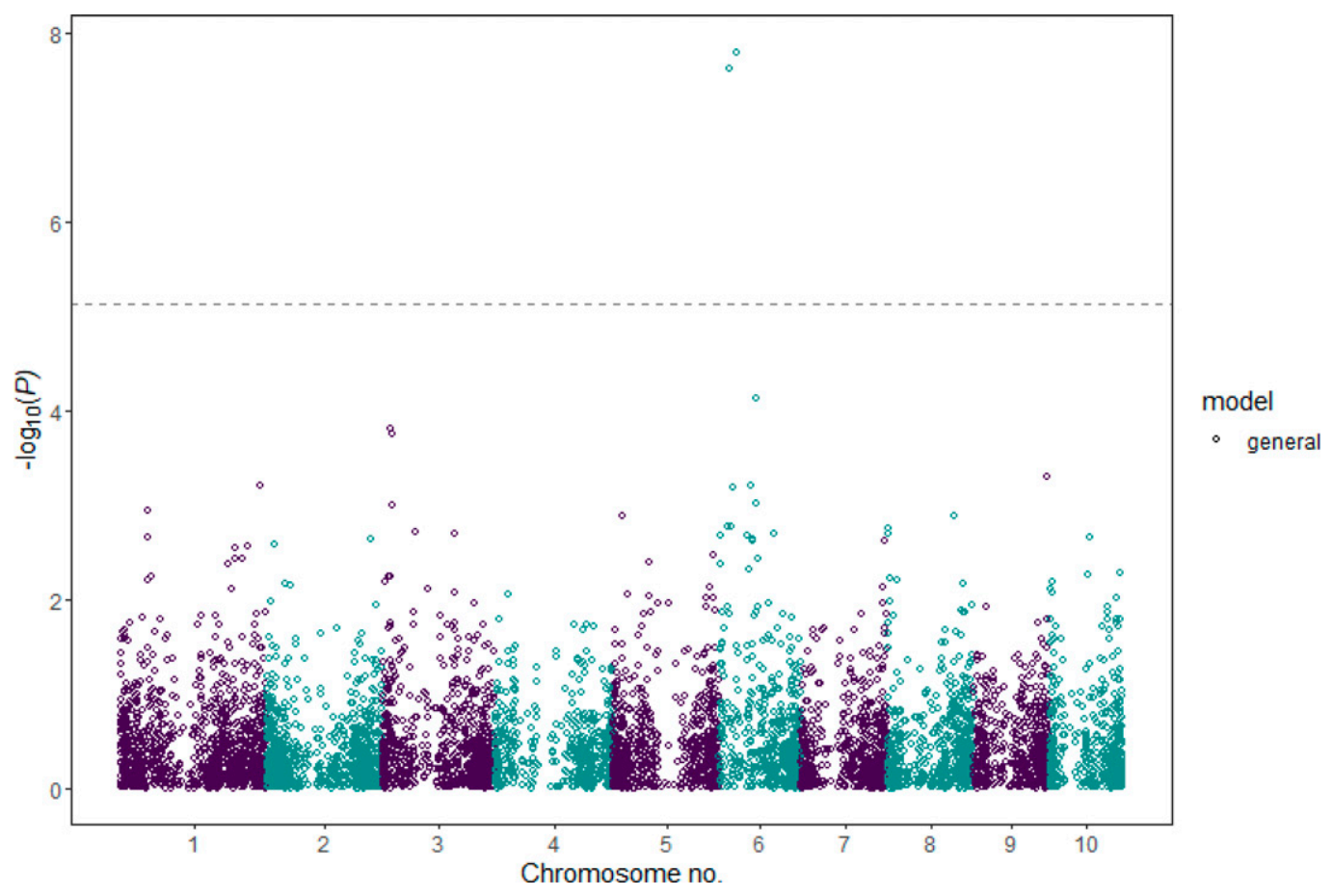

Fig. 5. Manhattan plot of susceptibility to Sugarcane mosaic virus genome-wide association study of 420 sweet corn inbreds within the Wisconsin Sweet Corn Diversity Panel. Logarithm of odds value with a 5\% Bonferroni threshold identified two loci within chromosome 6 in sweet corn.

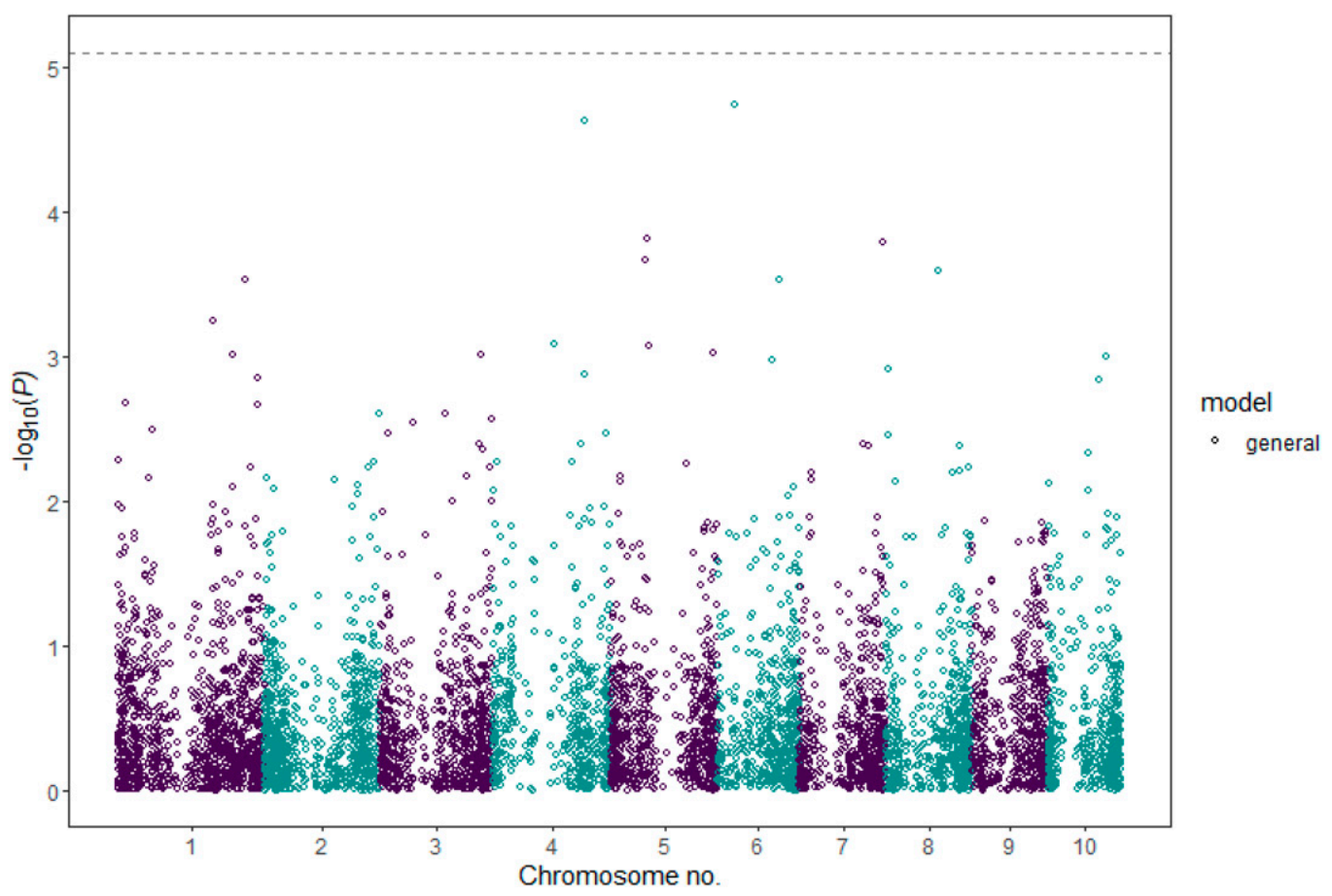

Fig. 6. Manhattan plot of susceptibility to Sugarcane mosaic virus genome-wide association study of 360 sweet corn inbreds within the Wisconsin Sweet Corn Diversity Panel that do not have the Scm 1- IL793a haplotype. Logarithm of odds value with a 5\% Bonferroni threshold identified no significant loci.

\section{Literature Cited}

Baseggio, M., M. Murray, M. Magallanes-Lundback, N. Kaczmar, J. Chamness, E.S. Buckler, M.E. Smith, D. DellaPenna, W.F. Tracy, and M.A. Gore. 2019. Genome-wide association and genomic prediction models of tocochromanols in fresh sweet corn kernels. Plant Genome 12(1):1-17, https://doi.org/10.3835/plantgenome2018.06.0038.
Baseggio, M., M. Murray, M. Magallanes-Lundback, N. Kaczmar, J. Chamness, E.S. Buckler, M.E. Smith, D. DellaPenna, W.F. Tracy, and M.A. Gore. 2020. Natural variation for carotenoids in fresh kernels is controlled by uncommon variants in sweet corn. Plant Genome 13(1):1-19, https://doi.org/10.1002/tpg2.20008.

Baseggio, M., M. Murray, D. Wu, G. Ziegler, N. Kaczmar, J. Chamness, J.P. Hamilton, C. Robin Buell, O.K. Vatamaniuk, E.S. Buckler, 
M.E. Smith, I. Baxter, W.F. Tracy, M.A. Gore, and D. Danforth. 2021. Genome-wide association study reveals an independent genetic basis of zinc and cadmium concentrations in fresh sweet corn kernels. BioRxiv 2021.02.19.432009, https://doi.org/10.1101/2021.02.19.432009.

Bradbury, P.J., Z. Zhang, D.E. Kroon, T.M. Casstevens, Y. Ramdoss, and E.S. Buckler. 2007. TASSEL: Software for association mapping of complex traits in diverse samples. Bioinformatics 23(19):2633-2635, https://doi.org/10.1093/bioinformatics/btm308.

Broekema, R.V., O.B. Bakker, and I.H. Jonkers. 2020. A practical view of fine-mapping and gene prioritization in the post-genome-wide association era. Open Biol. 10(1): https://doi.org/10.1098/rsob.190221.

Charpentier, L.J. 1956. Systemic insecticide studies for control of vectors and sugarcane mosaic in Louisiana. J. Econ. Entomol. 49(3):413-414, https://doi.org/10.1093/jee/49.3.413.

Dußle, C.M., A.E. Melchinger, L. Kuntze, A. Stork, and T. Lübberstedt. 2000. Molecular mapping and gene action of $\mathrm{Scm} 1$ and $\mathrm{Scm} 2$, two major QTL contributing to SCMV resistance in maize. Plant Breed. 119(4):299-303, https://doi.org/10.1046/j.1439-0523.2000.00509.x.

Dußle, C.M., M. Quint, A.E. Melchinger, M.L. Xu, and T. Lübberstedt. 2003. Saturation of two chromosome regions conferring resistance to SCMV with SSR and AFLP markers by targeted BSA. Theor. Appl. Genet. 106(3):485-493, https://doi.org/10.1007/s00122-002-1107-x.

Elshire, R.J., J.C. Glaubitz, Q. Sun, J.A. Poland, K. Kawamoto, E.S. Buckler, and S.E. Mitchell. 2011. A robust, simple genotyping-bysequencing (GBS) approach for high diversity species. PLoS One 6(5):1-10, https://doi.org/10.1371/journal.pone.0019379.

Flint-Garcia, S.A., J.M. Thornsberry, and E.S. Buckler. 2003. Structure of linkage disequilibrium in plants. Annu. Rev. Plant Biol. 54:357-374, https://doi.org/10.1146/annurev.arplant.54.031902.134907.

Fuchs, E. and M. Grüntzig. 1995. Influence of sugarcane mosaic virus (SCMV) and maize dwarf mosaic virus (MDMV) on the growth and yield of two maize varieties. J. Plant Dis. Prot. 102(1):44-50, https:// www.jstor.org/stable/43386365.

Gowda, M., B. Das, D. Makumbi, R. Babu, K. Semagn, G. Mahuku, M.S. Olsen, J.M. Bright, Y. Beyene, and B.M. Prasanna. 2015. Genome-wide association and genomic prediction of resistance to maize lethal necrosis disease in tropical maize germplasm. Theor. Appl. Genet. 128(10): 1957-1968, https://doi.org/10.1007/s00122-015-2559-0.

Gustafson, T.J., N. de Leon, S.M. Kaeppler, and W.F. Tracy. 2018. Genetic analysis of sugarcane mosaic virus resistance in the Wisconsin diversity panel of maize. Crop Sci. 58(5):1853-1865, https://doi. org/10.2135/cropsci2017.11.0675.

Hamazaki, K., H. Kajiya-Kanegae, M. Yamasaki, K. Ebana, S. Yabe, H. Nakagawa, and H. Iwata. 2020. Choosing the optimal population for a genome-wide association study: A simulation of whole-genome sequences from rice. Plant Genome 13(1):1-13, https://doi.org/10.1002/tpg2. 20005.

Johnson, H., D.H. Hall, W. Claxton, and W. Ishisaka. 1972. Sugarcane mosaic virus tolerance in sweet corn. Calif. Agr. 26(10):8-10.

Jones, M.W., M.G. Redinbaugh, and R. Louie. 2007. The Mdm1 locus and maize resistance to maize dwarf mosaic virus. Plant Dis. 91(2):185-190, https://doi.org/10.1094/PDIS-91-2-0185.

Knoke, J.K., R. Louie, R.J. Anderson, and D.T. Gordon. 1974. Distribution of MDMV and its aphid vectors in Ohio. Phytopathology 64:639-645.

Kuntze, L., E. Fuchs, M. Grüntzig, B. Schulz, U. Henning, F. Hohmann, and A. Melchinger. 1995. Evaluation of maize inbred Iines for resistance to sugarcane mosaic virus (SCMV) and maize dwarf mosaic virus (MDMV). Agronomie 15:463-467, https://doi.org/10.1051/agro: 19950714.

Kuntze, L., E. Fuchs, M. Grüntzig, B. Schulz, D. Klein, and A.E. Melchinger. 1997. Resistance of early-maturing European maize germplasm to sugarcane mosaic virus (SCMV) and maize dwarf mosaic virus (MDMV). Plant Breed. 116(5):499-501, https://doi.org/10.1111/ j.1439-0523.1997.tb01038.x.

Liu, Q., H. Liu, Y. Gong, Y. Tao, L. Jiang, W. Zuo, Q. Yang, J. Ye, J. Lai, J. Wu, T. Lübberstedt, and M. Xu. 2017. An atypical thioredoxin imparts early resistance to sugarcane mosaic virus in maize. Mol. Plant 10(3):483-497, https://doi.org/10.1016/j.molp.2017.02.002.

McMullen, M.D. and R. Louie. 1989. The linkage of molecular markers to a gene controlling the symptom response in maize to maize dwarf mosaic virus. Mol. Plant Microbe Interact. 2(6):309-314.

Melchinger, A.E., L. Kuntze, R.K. Gumber, T. Lübberstedt, and E. Fuchs. 1998. Genetic basis of resistance to sugarcane mosaic virus in European maize germplasm. Theor. Appl. Genet. 96(8):1151-1161, https://doi.org/10.1007/s001220050851.

Mikel, M.A., C.J. D'Arcy, A.M. Rhodes, and R.E. Ford. 1984. Genetics of resistance of two dent corn inbreds to maize dwarf mosaic virus and transfer of resistance into sweet corn. Phytopathology 74(4):467-473, https://doi.org/10.1094/phyto-74-467.

Pierce, S.E., A. Booms, J. Prahl, E.J.C. van der Schans, T. Tyson, and G.A. Coetzee. 2020. Post-GWAS knowledge gap: The how, where, and when. NPJ Parkinsons Dis. 6(1):1-5, https://doi.org/10.1038/ s41531-020-00125-y.

Portwood, J.L., M.R. Woodhouse, E.K. Cannon, J.M. Gardiner, L.C. Harper, M.L. Schaeffer, J.R. Walsh, T.Z. Sen, K.T. Cho, D.A. Schott, B.L. Braun, M. Dietze, B. Dunfee, C.G. Elsik, N. Manchanda, E. Coe, M. Sachs, P. Stinard, J. Tolbert, and C.M. Andorf. 2019. Maizegdb 2018: The maize multi-genome genetics and genomics database. Nucleic Acids Res. 47(D1):D1146-D1154, https:// doi.org/10.1093/nar/gky1046.

Romay, M.C., M.J. Millard, J.C. Glaubitz, J.A. Peiffer, K.L. Swarts, T.M. Casstevens, R.J. Elshire, C.B. Acharya, S.E. Mitchell, S.A. Flint-Garcia, M.D. McMullen, J.B. Holland, E.S. Buckler, and C.A. Gardner. 2013. Comprehensive genotyping of the USA national maize inbred seed bank. Genome Biol. 14(6):R55, https://doi.org/ 10.1186/gb-2013-14-6-r55.

Rosenkranz, E. and G.E. Scott. 1978. Effect of plant age at time of inoculation with maize dwarf mosaic virus on disease development and yield in corn. Phytopathology 68(12):1688, https://doi.org/ 10.1094/phyto-68-1688.

Rosyara, U.R., W.S. De Jong, D.S. Douches, and J.B. Endelman. 2016. Software for genome-wide association studies in autopolyploids and its application to potato. Plant Genome 9(2): https://doi. org/10.3835/plantgenome2015.08.0073.

Shukla, D.D., M.J. Frenkel, N.M. McKern, C.W. Ward, J. Jilka, M. Tosic, and R.E. Ford. 1992. Present status of the sugarcane mosaic subgroup of potyviruses. Arch. Virol. Suppl. 5:363-373, https://doi. org/10.1007/978-3-7091-6920-9_39.

Shukla, D.D., J. Jilka, M. Tosic, and R.E. Ford. 1989. A novel approach to the serology of potyviruses involving affinity- purified polycional antibodies directed towards virus-specific $\mathrm{N}$ termini of coat proteins. Genet. Virol. 70:13-23, https://doi.org/10.1099/0022-1317-70-1-13.

Simcox, K.D., M.D. McMullen, and R. Louie. 1995. Co-segregation of the maize dwarf mosaic virus resistance gene. Theor. Appl. Genet. 90:341-346, https://doi.org/10.1007/BF00221975.

Tao, Y., L. Jiang, Q. Liu, Y. Zhang, R. Zhang, C.R. Ingvardsen, U.K. Frei, B. Wang, J. Lai, T. Lübberstedt, and M. Xu. 2013. Combined linkage and association mapping reveals candidates for Scmv1, a major locus involved in resistance to sugarcane mosaic virus (SCMV) in maize. BMC Plant Biol. 13(1): https://doi.org/10.1186/1471-2229-13-162.

Użarowska, A., G. Dionisio, B. Sarholz, H.P. Piepho, M. Xu, C.R. Ingvardsen, G. Wenzel, and T. Lübberstedt. 2009. Validation of candidate genes putatively associated with resistance to SCMV and MDMV in maize (Zea mays L.) by expression profiling. BMC Plant Biol. 9:1-15, https://doi.org/10.1186/1471-2229-9-15.

VanRaden, P.M. 2008. Efficient methods to compute genomic predictions. J. Dairy Sci. 91(11):4414-4423, https://doi.org/10.3168/jds. 2007-0980.

Wangai, A.W., M.G. Redinbaugh, Z.M. Kinyua, D.W. Miano, P.K. Leley, M. Kasina, G. Mahuku, K. Scheets, and D. Jeffers. 2012. First report of maize chlorotic mottle virus and maize lethal necrosis in Kenya. Plant Dis. 96(10):1582, https://doi.org/10.1094/PDIS-06-12-0576-PDN. 
Xia, X., A.E. Melchinger, L. Kuntze, and T. Lübberstedt. 1999. Quantitative trait loci mapping of resistance to sugarcane mosaic virus in maize. Phytopathology 89(8):660-667, https://doi.org/10.1094/ PHYTO.1999.89.8.660.

Xiao, Y., H. Liu, L. Wu, M. Warburton, and J. Yan. 2017. Genomewide association studies in maize: Praise and stargaze. Mol. Plant 10(3):359-374, https://doi.org/10.1016/j.molp.2016.12.008.

Xing, Y., C. Ingvardsen, R. Salomon, and T. Lübberstedt. 2006. Analysis of sugarcane mosaic virus resistance in maize in an isogenic dihybrid crossing scheme and implications for breeding potyvirusresistant maize hybrids. Genome 49(10):1274-1282, https://doi.org/ 10.1139/G06-070.

Xu, M.L., A.E. Melchinger, and T. Lübberstedt. 2000. Origin of Scm1 and Scm2 - Two loci conferring resistance to sugarcane mosaic virus
(SCMV) in maize. Theor. Appl. Genet. 100(6):934-941, https://doi. org/10.1007/s001220051373.

Yuan, L., C.M. Dußle, A.E. Melchinger, H.F. Utz, and T. Lübberstedt. 2003. Clustering of QTL conferring SCMV resistance in maize. Maydica 48(1):55-62.

Zhang, S.H., X.H. Li, Z.H. Wang, M.L. George, D. Jeffers, F.G. Wang, X.D. Liu, M.S. Li, and L.X. Yuan. 2003. QTL mapping for resistance to SCMV in Chinese maize germplasm. Maydica 48(4):307-312.

Zheng, X., D. Levine, J. Shen, S.M. Gogarten, C. Laurie, and B.S. Weir. 2012. A high-performance computing toolset for relatedness and principal component analysis of SNP data. Bioinformatics 28(24):3326-3328, https://doi.org/10.1093/bioinfor matics/bts606. 




Supplemental Fig. 1. Linkage disequilibrium (LD) estimates among the 420 sequenced sweet corn inbreds. Mean decay of LD measured as pairwise $R^{2}$ from the 12,012 high-quality single-nucleotide polymorphism (SNP) markers over physical distance. Different percentile cutoffs are indicated of the distribution of SNP markers among all chromosomes. 
Supplemental Table 1. Phenotypic data for all sweet corn inbreds within screening, with information about planting order (pot label), ratio of sugarcane mosaic virus symptomatic plants, whether the line was sequence (genetic info), and had the haplotype associated with resistance within its sequence (Scm 1- IL793a haplotype), the inbreds' endosperm mutant type, and the inbreds' program of origin.



(Continued on next page) 
Supplemental Table 1. (Continued)



(Continued on next page) 
Supplemental Table 1. (Continued)

\begin{tabular}{|c|c|c|c|c|c|c|}
\hline Pot label & Inbred line & $\begin{array}{c}\text { Plants } \\
\text { symptomatic }(\%)^{\mathrm{z}}\end{array}$ & $\begin{array}{l}\text { Genetic } \\
\text { info }\end{array}$ & $\begin{array}{c}\text { Scm1- } \\
\text { IL793a haplotype }^{\mathrm{y}}\end{array}$ & $\begin{array}{l}\text { Endosperm } \\
\text { type }^{\mathrm{x}}\end{array}$ & $\begin{array}{c}\text { Program of } \\
\text { origin }^{w}\end{array}$ \\
\hline 226 & IL101T & 38 & TRUE & FALSE & su1 & IL \\
\hline 362 & Il101t su & 100 & FALSE & NA & NA & IL \\
\hline 52 & IL104g & 100 & TRUE & FALSE & su1 & IL \\
\hline 345 & IL107a & 67 & FALSE & NA & su1 & IL \\
\hline 249 & IL110K & 100 & TRUE & FALSE & su1 & IL \\
\hline 357 & IL1171 & 100 & TRUE & FALSE & su1 & IL \\
\hline 83 & IL11D & 100 & TRUE & FALSE & su1 & IL \\
\hline 44 & IL124a & 100 & TRUE & FALSE & su1 & IL \\
\hline 235 & IL 125a & 57 & FALSE & NA & NA & IL \\
\hline 150 & IL125b & 100 & TRUE & FALSE & su1 & IL \\
\hline 277 & IL134 & 50 & FALSE & NA & su1 & IL \\
\hline 300 & IL14H-1014:74 & 33 & TRUE & FALSE & sul & IL \\
\hline 161 & IL14H-588-68(B) & 100 & TRUE & FALSE & sul & IL \\
\hline 93 & IL18b & 100 & TRUE & FALSE & se & IL \\
\hline 193 & IL18c & 80 & FALSE & NA & NA & IL \\
\hline 266 & IL200e & 43 & TRUE & FALSE & su1 & IL \\
\hline 334 & IL21f & 67 & TRUE & FALSE & su1 & IL \\
\hline 36 & IL279AxRp1d & 100 & TRUE & FALSE & su1 & IL \\
\hline 135 & IL27a & 100 & TRUE & FALSE & su1 & IL \\
\hline 99 & IL27A-317-68ÂA & 100 & TRUE & FALSE & sul & IL \\
\hline 377 & IL303b & 86 & TRUE & FALSE & sul & IL \\
\hline 360 & IL318a & 75 & TRUE & FALSE & sul & IL \\
\hline 317 & IL369b & 43 & TRUE & FALSE & su1 & IL \\
\hline 55 & IL370a & 100 & TRUE & FALSE & su1 & IL \\
\hline 201 & IL370a (su) & 63 & TRUE & FALSE & su1 & IL \\
\hline 54 & IL370b & 100 & FALSE & NA & NA & IL \\
\hline 155 & IL393a & 75 & TRUE & FALSE & su1 & IL \\
\hline 56 & IL395a & 75 & TRUE & FALSE & su1 & IL \\
\hline 210 & IL430a & 100 & TRUE & FALSE & su1 & IL \\
\hline 188 & IL437a & 100 & TRUE & FALSE & su1 & IL \\
\hline 203 & IL442a & 100 & TRUE & FALSE & su1 & IL \\
\hline 370 & IL442A-431-68(D) & 75 & TRUE & FALSE & su1 & IL \\
\hline 351 & IL $44 b$ & 100 & TRUE & FALSE & se & IL \\
\hline 344 & IL451-18 Se Se & 71 & FALSE & NA & NA & IL \\
\hline 48 & IL451b & 100 & TRUE & FALSE & su1 & IL \\
\hline 102 & IL453b & 71 & TRUE & FALSE & su1 & IL \\
\hline 343 & IL454a & 86 & TRUE & FALSE & su1 & IL \\
\hline 121 & IL465a & 88 & TRUE & TRUE & su1 & IL \\
\hline 152 & IL47A & 100 & TRUE & FALSE & su1 & IL \\
\hline 308 & IL515a & 43 & TRUE & FALSE & su1 & IL \\
\hline 311 & IL543c & 67 & TRUE & FALSE & sul & IL \\
\hline 137 & IL545 & 100 & TRUE & FALSE & sul & IL \\
\hline 326 & IL557a & 63 & TRUE & FALSE & su1 & IL \\
\hline
\end{tabular}

(Continued on next page) 
Supplemental Table 1. (Continued)

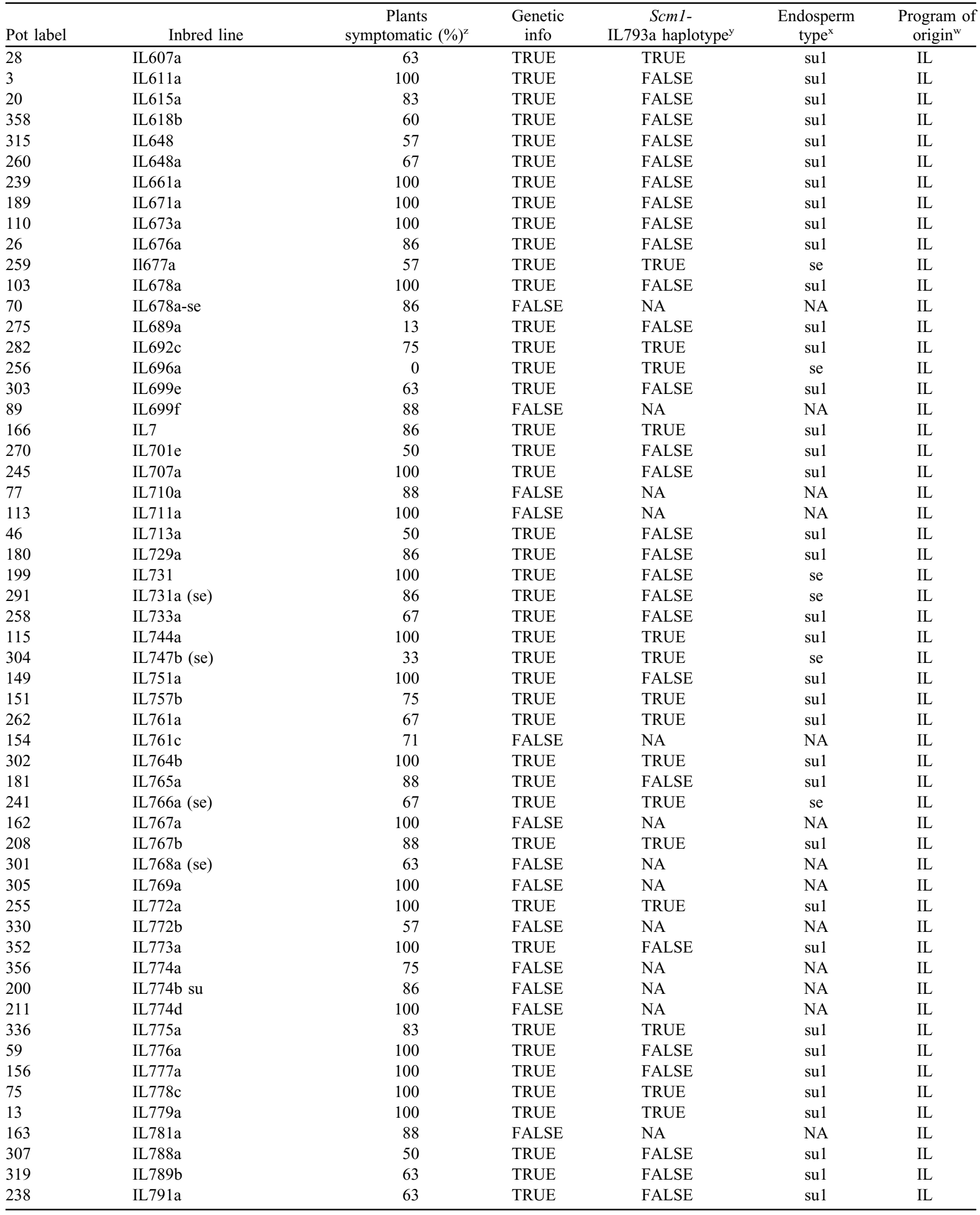

(Continued on next page) 
Supplemental Table 1. (Continued)

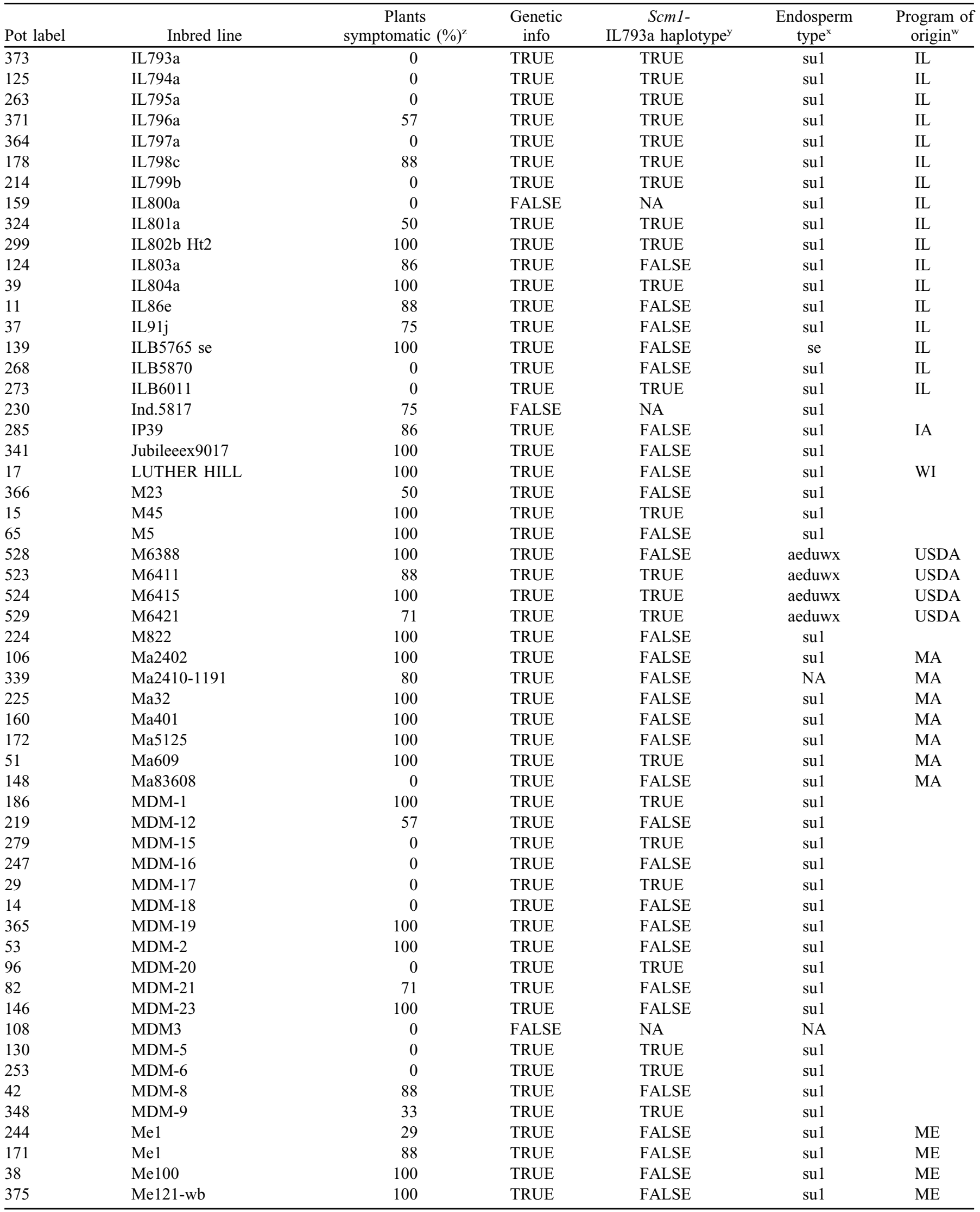

(Continued on next page) 
Supplemental Table 1. (Continued)

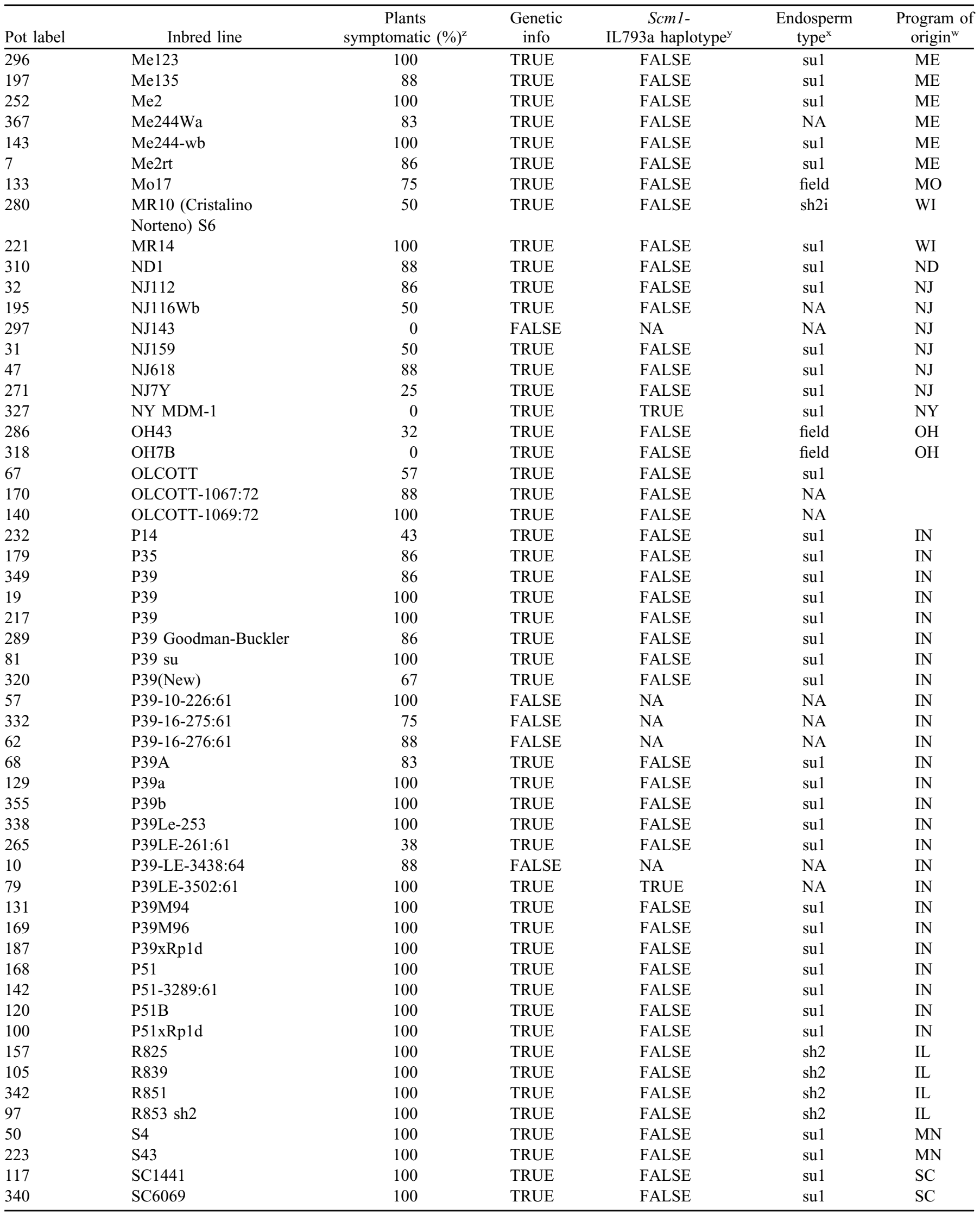

(Continued on next page) 
Supplemental Table 1. (Continued)

\begin{tabular}{|c|c|c|c|c|c|c|}
\hline Pot label & Inbred line & $\begin{array}{c}\text { Plants } \\
\text { symptomatic }(\%)^{\mathrm{z}}\end{array}$ & $\begin{array}{l}\text { Genetic } \\
\text { info }\end{array}$ & $\begin{array}{c}\text { Scml- } \\
\text { IL793a haplotype }\end{array}$ & $\begin{array}{c}\text { Endosperm } \\
\text { type }^{\mathrm{x}}\end{array}$ & $\begin{array}{c}\text { Program of } \\
\text { origin }^{\mathrm{w}}\end{array}$ \\
\hline 298 & SD176 & 100 & TRUE & FALSE & su1 & SD \\
\hline 374 & SD226 & 100 & TRUE & FALSE & su1 & SD \\
\hline 136 & SD277 & 88 & TRUE & FALSE & su1 & SD \\
\hline 2 & SD42 & 88 & TRUE & FALSE & su1 & $\mathrm{SD}$ \\
\hline 215 & SD469 & 100 & TRUE & FALSE & su1 & SD \\
\hline 1 & SD829 & 100 & TRUE & FALSE & su1 & SD \\
\hline 376 & SD883 & 43 & TRUE & FALSE & su1 & SD \\
\hline 78 & SD884 & 75 & TRUE & FALSE & su1 & SD \\
\hline 240 & SD908 & 100 & TRUE & FALSE & su1 & SD \\
\hline 213 & SD909 & 88 & TRUE & FALSE & su1 & SD \\
\hline 25 & STRAIN 304A-408-68B & 100 & TRUE & FALSE & sul & IL \\
\hline 309 & STRAIN 451B-4-68B & 75 & TRUE & FALSE & su1 & IL \\
\hline 328 & STRAIN 465A-421-68B & 34 & TRUE & TRUE & su1 & IL \\
\hline 92 & Strain 675A-415-68(B) & 100 & TRUE & FALSE & su1 & IL \\
\hline 5 & STRAIN T24-395-68B & 88 & TRUE & FALSE & sul & IL \\
\hline 361 & Strain T32-397-68r & 75 & TRUE & FALSE & sul & IL \\
\hline 184 & STRAIN T33-399-68B & 100 & TRUE & FALSE & su1 & IL \\
\hline 183 & STRAIN T35-388-68A & 88 & TRUE & FALSE & su1 & IL \\
\hline 306 & T20-2-68(B) & 29 & TRUE & FALSE & sul & IL \\
\hline 16 & T625 & 0 & TRUE & TRUE & sul & $\mathrm{TN}$ \\
\hline 111 & $\mathrm{~T} 62 \mathrm{~s}$ & 0 & TRUE & FALSE & su1 & $\mathrm{TN}$ \\
\hline 107 & W3722 & 88 & TRUE & FALSE & su1 & WI \\
\hline 337 & W3742 & 100 & TRUE & FALSE & su1 & WI \\
\hline 109 & W5543 & 100 & TRUE & FALSE & su1 & WI \\
\hline 175 & W5552 & 100 & TRUE & FALSE & su1 & WI \\
\hline 23 & W5579 & 88 & TRUE & FALSE & su1 & WI \\
\hline 218 & W6366 & 100 & TRUE & FALSE & su1 & WI \\
\hline 112 & W6462 & 100 & TRUE & FALSE & su1 & WI \\
\hline 66 & W64A & 38 & TRUE & TRUE & field & WI \\
\hline 312 & W6714 & 57 & TRUE & FALSE & su1 & WI \\
\hline 284 & W6720-1 & 88 & TRUE & FALSE & su1 & WI \\
\hline 21 & W6720-2 & NA & FALSE & NA & NA & WI \\
\hline 134 & W6728 & 100 & TRUE & FALSE & su1 & WI \\
\hline 177 & W6757 & 88 & TRUE & FALSE & su1 & WI \\
\hline 138 & W6786 & 100 & TRUE & FALSE & su1 & WI \\
\hline 167 & W6786 & 100 & TRUE & FALSE & su1 & WI \\
\hline 40 & W7151 & 63 & TRUE & FALSE & su1 & WI \\
\hline 451 & W822GSe & 63 & TRUE & FALSE & se & WI \\
\hline 278 & W85 & 75 & TRUE & FALSE & field & WI \\
\hline 464 & $\mathrm{We} 01407$ & 100 & TRUE & FALSE & se & WI \\
\hline 467 & $\mathrm{We} 02404$ & 100 & TRUE & FALSE & se & WI \\
\hline 462 & $\mathrm{We} 02412$ & 0 & TRUE & FALSE & se & WI \\
\hline
\end{tabular}

(Continued on next page) 
Supplemental Table 1. (Continued)

\begin{tabular}{|c|c|c|c|c|c|c|}
\hline Pot label & Inbred line & $\begin{array}{c}\text { Plants } \\
\text { symptomatic }(\%)^{\mathrm{z}}\end{array}$ & $\begin{array}{l}\text { Genetic } \\
\text { info }\end{array}$ & $\begin{array}{c}S c m 1- \\
\text { IL 793a haplotype }^{y}\end{array}$ & $\begin{array}{c}\text { Endosperm } \\
\text { type }^{\mathrm{x}}\end{array}$ & $\begin{array}{c}\text { Program of } \\
\text { origin }^{w} \\
\end{array}$ \\
\hline$\overline{425}$ & $\mathrm{We} 03418 \mathrm{a}$ & 83 & TRUE & FALSE & $\mathrm{se}$ & WI \\
\hline 417 & We04401 & 86 & FALSE & NA & se & WI \\
\hline 463 & We04806 & 100 & FALSE & NA & se & WI \\
\hline 542 & We05401 & 88 & TRUE & FALSE & se & WI \\
\hline 563 & $\mathrm{We} 05408$ & 100 & TRUE & FALSE & se & WI \\
\hline 411 & $\mathrm{We} 05410$ & 75 & TRUE & FALSE & se & WI \\
\hline 546 & We05411 & 83 & TRUE & FALSE & se & WI \\
\hline 540 & We06409b & 100 & TRUE & FALSE & se & WI \\
\hline 559 & we $07403 a$ & 100 & FALSE & NA & se & WI \\
\hline 468 & We08405 & 63 & FALSE & NA & se & WI \\
\hline 388 & We08408 & 71 & TRUE & FALSE & se & WI \\
\hline 421 & We08414a & 67 & TRUE & FALSE & se & WI \\
\hline 466 & $\mathrm{We} 08424$ & 57 & FALSE & NA & se & WI \\
\hline 483 & We09402 & 75 & TRUE & FALSE & se & WI \\
\hline 416 & We09413 & 100 & TRUE & FALSE & se & WI \\
\hline 410 & We09425 & 100 & TRUE & FALSE & se & WI \\
\hline 482 & We10401 & 48 & TRUE & FALSE & se & WI \\
\hline 519 & We11401 & 75 & FALSE & NA & se & WI \\
\hline 556 & We11404 & 63 & FALSE & NA & se & WI \\
\hline 450 & We11405 & 83 & FALSE & NA & NA & WI \\
\hline 543 & we11416 & 88 & FALSE & NA & se & WI \\
\hline 557 & we12401 & 100 & FALSE & NA & se & WI \\
\hline 446 & Wh00033 & 86 & TRUE & FALSE & $\operatorname{sh} 2$ & WI \\
\hline 505 & Wh00050 & 75 & TRUE & FALSE & $\operatorname{sh} 2$ & WI \\
\hline 495 & Wh00051 & 100 & TRUE & FALSE & $\operatorname{sh} 2$ & WI \\
\hline 561 & Wh00065 & 100 & TRUE & FALSE & $\operatorname{sh} 2$ & WI \\
\hline 497 & Wh01001 & 63 & TRUE & FALSE & $\operatorname{sh} 2$ & WI \\
\hline 383 & Wh03031 & 86 & TRUE & FALSE & $\operatorname{sh} 2$ & WI \\
\hline 480 & Wh04020a & 50 & TRUE & FALSE & $\operatorname{sh} 2$ & WI \\
\hline 552 & Wh05032a & 100 & TRUE & FALSE & $\operatorname{sh} 2$ & WI \\
\hline 384 & Wh05051 & 100 & TRUE & FALSE & $\operatorname{sh} 2$ & WI \\
\hline 481 & Wh05066a & 60 & TRUE & FALSE & $\operatorname{sh} 2$ & WI \\
\hline 493 & Wh05070a & 50 & FALSE & NA & $\operatorname{sh} 2$ & WI \\
\hline 449 & Wh05081b & 86 & TRUE & FALSE & $\operatorname{sh} 2$ & WI \\
\hline 551 & Wh05081b & 100 & TRUE & FALSE & $\operatorname{sh} 2$ & WI \\
\hline 395 & Wh07013 & NA & TRUE & FALSE & $\operatorname{sh} 2$ & WI \\
\hline 444 & Wh07020a & 67 & TRUE & FALSE & $\operatorname{sh} 2$ & WI \\
\hline 440 & Wh07029 & 67 & FALSE & NA & $\operatorname{sh} 2$ & WI \\
\hline 390 & Wh07051 & NA & TRUE & FALSE & $\operatorname{sh} 2$ & WI \\
\hline 433 & Wh07061a & 75 & TRUE & FALSE & $\operatorname{sh} 2$ & WI \\
\hline 456 & Wh07061b & 75 & FALSE & NA & $\operatorname{sh} 2$ & WI \\
\hline 429 & Wh07165R & 100 & TRUE & FALSE & $\operatorname{sh} 2$ & WI \\
\hline 432 & Wh07166R & 80 & TRUE & FALSE & $\operatorname{sh} 2$ & WI \\
\hline 424 & Wh08022 & 88 & TRUE & FALSE & $\operatorname{sh} 2$ & WI \\
\hline 502 & Wh08039 & 100 & FALSE & NA & $\operatorname{sh} 2$ & WI \\
\hline 431 & Wh08042 & 86 & TRUE & FALSE & $\operatorname{sh} 2$ & WI \\
\hline 492 & Wh08045 & 88 & FALSE & NA & $\operatorname{sh} 2$ & WI \\
\hline 428 & Wh08092 & 67 & TRUE & FALSE & $\operatorname{sh} 2$ & WI \\
\hline 562 & Wh08114 & 75 & FALSE & NA & $\operatorname{sh} 2$ & WI \\
\hline 499 & Wh08114 & 88 & FALSE & NA & $\operatorname{sh} 2$ & WI \\
\hline 544 & Wh08115b & 86 & TRUE & FALSE & $\operatorname{sh} 2$ & WI \\
\hline 381 & Wh09009 & 67 & TRUE & FALSE & $\operatorname{sh} 2$ & WI \\
\hline 409 & Wh09033 & 100 & TRUE & FALSE & $\operatorname{sh} 2$ & WI \\
\hline 426 & Wh09061 & 60 & TRUE & FALSE & $\operatorname{sh} 2$ & WI \\
\hline 427 & Wh09068 & 80 & TRUE & FALSE & $\operatorname{sh} 2$ & WI \\
\hline 454 & Wh09075 & 100 & TRUE & FALSE & $\operatorname{sh} 2$ & WI \\
\hline
\end{tabular}

(Continued on next page) 
Supplemental Table 1. (Continued)

\begin{tabular}{|c|c|c|c|c|c|c|}
\hline Pot label & Inbred line & $\begin{array}{c}\text { Plants } \\
\text { symptomatic }(\%)^{\mathrm{z}}\end{array}$ & $\begin{array}{l}\text { Genetic } \\
\text { info }\end{array}$ & $\begin{array}{c}S c m 1- \\
\text { IL793a haplotype }^{\mathrm{y}}\end{array}$ & $\begin{array}{c}\text { Endosperm } \\
\text { type }^{\mathrm{x}}\end{array}$ & $\begin{array}{c}\text { Program of } \\
\text { origin }^{w} \\
\end{array}$ \\
\hline$\overline{445}$ & Wh09083 & 63 & TRUE & FALSE & $\operatorname{sh} 2$ & $\overline{W I}$ \\
\hline 531 & Wh09086 & 100 & FALSE & NA & $\operatorname{sh} 2$ & WI \\
\hline 541 & Wh09087 & 100 & TRUE & FALSE & $\operatorname{sh} 2$ & WI \\
\hline 420 & Wh09117R & 100 & TRUE & FALSE & $\operatorname{sh} 2$ & WI \\
\hline 379 & Wh09126R & 63 & TRUE & FALSE & $\operatorname{sh} 2$ & WI \\
\hline 408 & Wh09137R & 57 & TRUE & FALSE & $\operatorname{sh} 2$ & WI \\
\hline 412 & Wh09141R & 75 & TRUE & FALSE & $\operatorname{sh} 2$ & WI \\
\hline 477 & Wh10006R & 50 & TRUE & TRUE & $\operatorname{sh} 2$ & WI \\
\hline 430 & Wh10034R & 100 & TRUE & FALSE & $\operatorname{sh} 2$ & WI \\
\hline 484 & Wh10035R & 68 & TRUE & FALSE & $\operatorname{sh} 2$ & WI \\
\hline 485 & Wh10040R & 71 & FALSE & NA & $\operatorname{sh} 2$ & WI \\
\hline 393 & Wh10046R & 63 & TRUE & FALSE & $\operatorname{sh} 2$ & WI \\
\hline 500 & Wh10049R & 88 & TRUE & FALSE & $\operatorname{sh} 2$ & WI \\
\hline 496 & Wh10052R & 100 & FALSE & NA & $\operatorname{sh} 2$ & WI \\
\hline 491 & Wh10057R & 100 & FALSE & NA & $\operatorname{sh} 2$ & WI \\
\hline 400 & Wh10062R & 83 & TRUE & FALSE & $\operatorname{sh} 2$ & WI \\
\hline 472 & Wh10067R & 83 & FALSE & NA & $\operatorname{sh} 2$ & WI \\
\hline 512 & Wh10067R & 100 & FALSE & NA & $\operatorname{sh} 2$ & WI \\
\hline 514 & Wh10068R & 100 & FALSE & NA & $\operatorname{sh} 2$ & WI \\
\hline 479 & Wh10070R & 100 & FALSE & NA & $\operatorname{sh} 2$ & WI \\
\hline 435 & Wh10080 & 50 & TRUE & FALSE & $\operatorname{sh} 2$ & WI \\
\hline 536 & Wh10085 & 100 & FALSE & NA & NA & WI \\
\hline 537 & Wh10088R & 86 & FALSE & NA & $\operatorname{sh} 2$ & WI \\
\hline 452 & Wh10090R & 100 & FALSE & NA & $\operatorname{sh} 2$ & WI \\
\hline 441 & Wh10105R & 83 & FALSE & NA & $\operatorname{sh} 2$ & WI \\
\hline 415 & Wh10110R & 100 & TRUE & TRUE & $\operatorname{sh} 2$ & WI \\
\hline 406 & Wh10113R & 50 & TRUE & FALSE & $\operatorname{sh} 2$ & WI \\
\hline 532 & wh10117R & 100 & FALSE & NA & $\operatorname{sh} 2$ & WI \\
\hline 506 & Wh10127R & 50 & FALSE & NA & $\operatorname{sh} 2$ & WI \\
\hline 507 & Wh10135R & 80 & FALSE & NA & $\operatorname{sh} 2$ & WI \\
\hline 465 & Wh10137R & 63 & FALSE & NA & $\operatorname{sh} 2$ & WI \\
\hline 436 & Wh10140R & 0 & TRUE & FALSE & $\operatorname{sh} 2$ & WI \\
\hline 476 & Wh10163 & 23 & TRUE & TRUE & $\operatorname{sh} 2$ & WI \\
\hline 439 & Wh10173V & 0 & TRUE & TRUE & $\operatorname{sh} 2$ & WI \\
\hline 498 & Wh10216V & 0 & TRUE & TRUE & $\operatorname{sh} 2$ & WI \\
\hline 407 & Wh10231V & 0 & TRUE & TRUE & $\operatorname{sh} 2$ & WI \\
\hline 549 & Wh10804R & 88 & TRUE & TRUE & $\operatorname{sh} 2$ & WI \\
\hline 520 & Wh11001 & 57 & FALSE & NA & $\operatorname{sh} 2$ & WI \\
\hline 402 & Wh11005 & 0 & FALSE & NA & $\operatorname{sh} 2$ & WI \\
\hline 535 & Wh11008 & 100 & FALSE & NA & $\operatorname{sh} 2$ & WI \\
\hline 489 & Wh12001 & 67 & FALSE & NA & $\operatorname{sh} 2$ & WI \\
\hline 469 & Wh12004 & 71 & FALSE & NA & $\operatorname{sh} 2$ & WI \\
\hline 389 & Wh12005 & 100 & FALSE & NA & $\operatorname{sh} 2$ & WI \\
\hline 503 & Wh12008 & 50 & FALSE & NA & $\operatorname{sh} 2$ & WI \\
\hline 458 & Wh12014 & 0 & FALSE & NA & $\operatorname{sh} 2$ & WI \\
\hline 490 & Wh12048V & 0 & FALSE & NA & $\operatorname{sh} 2$ & WI \\
\hline 396 & Wh13022A & 0 & FALSE & NA & $\operatorname{sh} 2$ & WI \\
\hline 385 & Wh13037 & 86 & FALSE & NA & $\operatorname{sh} 2$ & WI \\
\hline 478 & Wh13040 & 50 & FALSE & NA & $\operatorname{sh} 2$ & WI \\
\hline 399 & Wh13041 & 86 & FALSE & NA & $\operatorname{sh} 2$ & WI \\
\hline 382 & Wh13048 & 67 & FALSE & NA & $\operatorname{sh} 2$ & WI \\
\hline 447 & Wh13053 & 57 & FALSE & NA & $\operatorname{sh} 2$ & WI \\
\hline 405 & Wh13063A & 0 & FALSE & NA & $\operatorname{sh} 2$ & WI \\
\hline 459 & Wh13064 & 21 & FALSE & NA & $\operatorname{sh} 2$ & WI \\
\hline 403 & Wh13070 & 0 & FALSE & NA & $\operatorname{sh} 2$ & WI \\
\hline 392 & Wh13074 & 0 & FALSE & NA & $\operatorname{sh} 2$ & WI \\
\hline
\end{tabular}

(Continued on next page) 
Supplemental Table 1. (Continued)

\begin{tabular}{|c|c|c|c|c|c|c|}
\hline Pot label & Inbred line & $\begin{array}{c}\text { Plants } \\
\text { symptomatic }(\%)^{\mathrm{z}}\end{array}$ & $\begin{array}{l}\text { Genetic } \\
\text { info }\end{array}$ & $\begin{array}{c}S c m 1- \\
\text { IL 793a haplotype }^{y}\end{array}$ & $\begin{array}{c}\text { Endosperm } \\
\text { type }^{\mathrm{x}}\end{array}$ & $\begin{array}{c}\text { Program of } \\
\text { origin }^{w} \\
\end{array}$ \\
\hline$\overline{494}$ & Wh14100V & 100 & FALSE & NA & $\operatorname{sh} 2$ & WI \\
\hline 461 & Wh92047 & 0 & TRUE & TRUE & $\operatorname{sh} 2$ & WI \\
\hline 457 & Wh9261 & 67 & TRUE & FALSE & $\operatorname{sh} 2$ & WI \\
\hline 554 & Wh93006 & 100 & TRUE & FALSE & $\operatorname{sh} 2$ & WI \\
\hline 501 & Wh93016 & 100 & TRUE & FALSE & $\operatorname{sh} 2$ & WI \\
\hline 545 & Wh93017 & 100 & TRUE & FALSE & $\operatorname{sh} 2$ & WI \\
\hline 553 & Wh94053 & 100 & TRUE & FALSE & $\operatorname{sh} 2$ & WI \\
\hline 460 & Wh95016a & 100 & TRUE & FALSE & $\operatorname{sh} 2$ & WI \\
\hline 548 & Wh96015 & 100 & FALSE & NA & $\operatorname{sh} 2$ & WI \\
\hline 471 & Wh96034 & 100 & TRUE & FALSE & $\operatorname{sh} 2$ & WI \\
\hline 470 & Wh98044 & 83 & TRUE & FALSE & $\operatorname{sh} 2$ & WI \\
\hline 555 & Wh98044 & 100 & TRUE & FALSE & $\operatorname{sh} 2$ & WI \\
\hline 418 & Wh98063 & 86 & TRUE & FALSE & $\operatorname{sh} 2$ & WI \\
\hline 378 & Wu00801 & 80 & TRUE & FALSE & su1 & WI \\
\hline 558 & Wu00802 & 100 & TRUE & FALSE & su1 & WI \\
\hline 518 & Wu0184R & 57 & FALSE & NA & NA & WI \\
\hline 487 & Wu04819 & 60 & TRUE & FALSE & su1 & WI \\
\hline 508 & Wu10802R & 75 & TRUE & FALSE & su1 & WI \\
\hline 509 & Wu99811 & 86 & TRUE & FALSE & sul & WI \\
\hline 510 & Wu99823 & 71 & TRUE & FALSE & su1 & WI \\
\hline 386 & Wuh07177i & 63 & TRUE & FALSE & $\operatorname{sh} 2 \mathrm{i}$ & WI \\
\hline 560 & wuh07182i & 100 & TRUE & FALSE & $\operatorname{sh} 2 \mathrm{i}$ & WI \\
\hline 547 & Wuh07183i & 100 & TRUE & FALSE & $\operatorname{sh} 2 \mathrm{i}$ & WI \\
\hline 438 & Wuh07186i & 100 & TRUE & FALSE & $\operatorname{sh} 2 \mathrm{i}$ & WI \\
\hline 533 & Wuh07413 & 60 & TRUE & FALSE & $\operatorname{sh} 2 \mathrm{i}$ & WI \\
\hline 423 & Wuh07422i & 67 & TRUE & FALSE & $\operatorname{sh} 2 \mathrm{i}$ & WI \\
\hline 521 & Wuh07428i & 33 & FALSE & NA & $\operatorname{sh} 2 \mathrm{i}$ & WI \\
\hline 448 & Wuh07429i & 80 & TRUE & FALSE & $\operatorname{sh} 2 \mathrm{i}$ & WI \\
\hline 455 & Wuh07466i & 50 & TRUE & FALSE & $\operatorname{sh} 2$ & WI \\
\hline 486 & Wuh07469i & 0 & TRUE & FALSE & $\operatorname{sh} 2 \mathrm{i}$ & WI \\
\hline 443 & Wuh07481i & 100 & TRUE & FALSE & $\operatorname{sh} 2 \mathrm{i}$ & WI \\
\hline 522 & Wuh07492i & 50 & FALSE & NA & $\operatorname{sh} 2 \mathrm{i}$ & WI \\
\hline 404 & Wuh08127ia & 75 & TRUE & FALSE & $\operatorname{sh} 2 \mathrm{i}$ & WI \\
\hline 474 & Wuh09093i & 50 & TRUE & FALSE & $\operatorname{sh} 2 \mathrm{i}$ & WI \\
\hline 387 & Wuh09097i & 60 & TRUE & FALSE & $\operatorname{sh} 2 \mathrm{i}$ & WI \\
\hline 422 & Wuh09098i & 75 & TRUE & FALSE & $\operatorname{sh} 2 \mathrm{i}$ & WI \\
\hline 434 & Wuh09144i & 86 & TRUE & FALSE & $\operatorname{sh} 2 \mathrm{i}$ & WI \\
\hline 413 & Wuh09149i & 100 & TRUE & FALSE & $\operatorname{sh} 2 \mathrm{i}$ & WI \\
\hline 414 & Wuh09150i & 75 & TRUE & FALSE & $\operatorname{sh} 2 \mathrm{i}$ & WI \\
\hline 475 & Wuh09153i & 33 & TRUE & FALSE & $\operatorname{sh} 2 \mathrm{i}$ & WI \\
\hline 380 & Wuh09164i & 86 & TRUE & FALSE & $\operatorname{sh} 2 \mathrm{i}$ & WI \\
\hline 391 & Wuh09170i & 60 & TRUE & FALSE & $\operatorname{sh} 2 \mathrm{i}$ & WI \\
\hline 473 & Wuh09174i & 75 & TRUE & FALSE & $\operatorname{sh} 2 \mathrm{i}$ & WI \\
\hline 394 & Wuh09183i & 100 & TRUE & FALSE & $\operatorname{sh} 2 \mathrm{i}$ & WI \\
\hline 437 & Wuh09188i & 67 & TRUE & FALSE & $\operatorname{sh} 2 \mathrm{i}$ & WI \\
\hline 419 & Wuh09191i & 100 & TRUE & FALSE & $\operatorname{sh} 2 \mathrm{i}$ & WI \\
\hline 530 & Wuh11801i & 75 & FALSE & NA & $\operatorname{sh} 2 \mathrm{i}$ & WI \\
\hline 539 & Wuh11805i & 100 & FALSE & NA & $\operatorname{sh} 2 \mathrm{i}$ & WI \\
\hline 527 & Wuh11809i & 67 & FALSE & NA & $\operatorname{sh} 2 \mathrm{i}$ & WI \\
\hline 516 & Wuh11810i & 100 & FALSE & NA & $\operatorname{sh} 2 \mathrm{i}$ & WI \\
\hline 526 & Wuh11811i & 88 & FALSE & NA & $\operatorname{sh} 2 \mathrm{i}$ & WI \\
\hline 538 & Wuh11812i & 88 & FALSE & NA & $\operatorname{sh} 2 \mathrm{i}$ & WI \\
\hline 515 & Wuh11813i & 100 & FALSE & NA & $\operatorname{sh} 2 \mathrm{i}$ & WI \\
\hline 453 & Wuh11816i & 100 & FALSE & NA & $\operatorname{sh} 2 \mathrm{i}$ & WI \\
\hline 488 & Wuh12018i & 100 & FALSE & NA & $\operatorname{sh} 2 \mathrm{i}$ & WI \\
\hline 397 & Wuh12019i & 100 & FALSE & NA & $\operatorname{sh} 2 \mathrm{i}$ & WI \\
\hline
\end{tabular}

(Continued on next page) 
Supplemental Table 1. (Continued)

\begin{tabular}{|c|c|c|c|c|c|c|}
\hline Pot label & Inbred line & $\begin{array}{c}\text { Plants } \\
\text { symptomatic }(\%)^{\mathrm{z}}\end{array}$ & $\begin{array}{l}\text { Genetic } \\
\text { info }\end{array}$ & $\begin{array}{c}\text { Scm1- } \\
\text { IL793a haplotype }^{\mathrm{y}}\end{array}$ & $\begin{array}{l}\text { Endosperm } \\
\text { type }^{\mathrm{x}}\end{array}$ & $\begin{array}{l}\text { Program of } \\
\text { origin }^{w}\end{array}$ \\
\hline$\overline{511}$ & Wuh12020i & 100 & FALSE & NA & $\operatorname{sh} 2 \mathrm{i}$ & WI \\
\hline 513 & Wuh12027i & 100 & FALSE & NA & $\operatorname{sh} 2 \mathrm{i}$ & WI \\
\hline 504 & Wuh12037i & 100 & FALSE & NA & $\operatorname{sh} 2 \mathrm{i}$ & WI \\
\hline 398 & Wuh12039i & 67 & FALSE & NA & $\operatorname{sh} 2 \mathrm{i}$ & WI \\
\hline 442 & Wuh98032 & 86 & TRUE & FALSE & $\operatorname{sh} 2$ & WI \\
\hline
\end{tabular}

${ }^{\mathrm{z}}$ Plants symptomatic percentage was determined by taking the number of plants symptomatic for sugarcane mosaic virus and dividing by the total number of plants per pot from all replicates

${ }^{\mathrm{y}} \mathrm{Scm}$ 1- IL793a haplotype was determined for genotyped inbreds by comparing their haplotype near the Scm1 locus to IL793a, an inbred with known to have the Scml.

${ }^{\mathrm{x}}$ Endosperm mutants types are aeduwx $=$ amylose-extender: dull: waxy; se $=$ sugary enhancer; $\operatorname{sh} 2=\operatorname{shrunken} 2 ; \operatorname{sh} 2 \mathrm{i}=\operatorname{shrunken} 2$ intermediate; su1 = sugary 1 .

${ }^{\mathrm{w}} \mathrm{CT}=$ University of Connecticut-Storrs, CT; FL = University of Florida-Gainesville, FL; FR = National Institute of Agricultural Research (Paris, France); GA = University of Georgia-Athens; IA = Iowa State University-Ames, IA; IL = University of Illinois-Champaign; IN = Purdue University (West Lafayette, IN); MA = University of Massachusetts-Amherst; ME = University of Maine-Orono, ME; MN = University of Minnesota (Minneapolis, MN); MO = University of Missouri-Columbia. ND = North Dakota State University of Agriculture and Applied Sciences (Fargo, ND); NJ = Rutgers, The State University of New Jersey (Brunswick, NJ); NY = Cornell University (Ithaca, $\mathrm{NY}$ ); $\mathrm{OH}=$ The Ohio State University (Columbus, $\mathrm{OH}$ ); $\mathrm{SC}=$ Clemson University (Clemson, SC); SD = South Dakota State University (Brookings, SD); SP = Spanish National Research Council (Pontevedra, Spain); TN = University of Tennessee-(Knoxville; USDA = U.S. Department of Agriculture (Washington, DC); WI = University of Wisconsin-Madison; NA = not applicable.

Supplemental Table 2. Zea mays genes associated with the significant locus S6_19987285 found in the susceptibility-to-sugarcane mosaic virus genome-wide association study.

\begin{tabular}{|c|c|c|c|}
\hline Associated gene model $^{\mathrm{z}}$ & Model type ${ }^{y}$ & Location & Gene description \\
\hline$\overline{\text { GRMZM2G037500 }}$ & PCD & (Chr6: 19847399.19851546) & \\
\hline AC203396.3_FG003 & $\mathrm{TE}$ & (Chr6: 19973765.19988320) & gbptf1 (GeBP-transcription factor 1$)$ \\
\hline GRMZM2G147637 & $\mathrm{LC}$ & (Chr6: 19872033.19878792) & \\
\hline GRMZM2G392516 & PCD & (Chr6: 19960725.19967788) & gbptf1 (GeBP-transcription factor 1) \\
\hline GRMZM2G384990 & $\mathrm{LC}$ & (Chr6: 19985350.19988797) & gbptf1 (GeBP-transcription factor 1) \\
\hline GRMZM5G856609 & $\mathrm{LC}$ & (Chr6: 19985470.19988699) & gbptf1 (GeBP-transcription factor 1) \\
\hline GRMZM2G533307 & $\mathrm{LC}$ & (Chr6: 19985815.19988915) & \\
\hline GRMZM2G533313 & $\mathrm{LC}$ & (Chr6: 20014034.20017176) & \\
\hline GRMZM2G058741 & TE & (Chr6: 20058058.20061531) & \\
\hline LOC103629131 & PCD & & period circadian protein homolog 2 \\
\hline GRMZM5G802354 & PCD & (Chr6: 20213684.20217652) & \\
\hline
\end{tabular}

${ }_{\mathrm{z}}$ Associated gene model referenced from Maize B73 Refgen v3.

${ }^{\mathrm{y}}$ Model types are $\mathrm{LC}=$ low confidence; $\mathrm{PCD}=$ protein coding; $\mathrm{TE}=$ transposable element. 
Supplemental Table 3. Zea mays genes associated with the significant locus S6_36947510 found in the susceptibility-to-sugarcane mosaic virus genome-wide association study.

\begin{tabular}{|c|c|c|c|}
\hline Associated gene model $^{\mathrm{z}}$ & Model type ${ }^{y}$ & Location & Gene description \\
\hline$\overline{\text { GRMZM2G581005 }}$ & $\mathrm{LC}$ & (Chr6: 36807922.36811018) & \\
\hline GRMZM2G571740 & $\mathrm{LC}$ & (Chr6: 36895611.36900999) & \\
\hline GRMZM2G581004 & TE & (Chr6: 36821164.36824302) & \\
\hline GRMZM2G581002 & $\mathrm{LC}$ & (Chr6: 36831156.36834257) & \\
\hline GRMZM2G432999 & $\mathrm{LC}$ & (Chr6: 36858137.36862112) & 2 leaf expansion stage \\
\hline GRMZM2G532195 & $\mathrm{TE}$ & (Chr6: 37170575.37173682) & \\
\hline GRMZM5G858648 & TE & (Chr6: 37026108.37033894) & \\
\hline GRMZM2G179069 & PCD & (Chr6: 36945138.36950105) & dof3 (DNA binding with one finger3) \\
\hline GRMZM2G486245 & $\mathrm{TE}$ & (Chr6: 36971750.36975125$)$ & \\
\hline GRMZM5G883412 & $\mathrm{LC}$ & (Chr6: 37074520.37077940$)$ & \\
\hline GRMZM5G837567 & TE & (Chr6: 37076232.37081427) & \\
\hline AC197336.3_FG001 & TE & (Chr6: 36972387.36975488) & \\
\hline GRMZM5G876606 & $\mathrm{LC}$ & (Chr6: 36946563.36949718) & dof3 (DNA binding with one finger3) \\
\hline GRMZM2G021909 & PCD & (Chr6: 37023635.37028921) & \\
\hline GRMZM2G493573 & $\mathrm{LC}$ & (Chr6: 37045645.37048735) & \\
\hline GRMZM2G021931 & $\mathrm{LC}$ & (Chr6: 37046349.37050104) & \\
\hline GRMZM2G383019 & $\mathrm{LC}$ & (Chr6: 37175236.37181956) & \\
\hline GRMZM2G581000 & $\mathrm{LC}$ & (Chr6: 36831737.36834834$)$ & \\
\hline AC187244.4_FG004 & $\mathrm{LC}$ & (Chr6: 36832550.36837598) & \\
\hline GRMZM5G858648 & TE & (Chr6: 37026108.37033894) & \\
\hline
\end{tabular}

${ }^{\mathrm{z}}$ Associated gene model referenced from Maize B73 Refgen v3.

${ }^{\mathrm{y}}$ Model types are $\mathrm{LC}=$ low confidence; $\mathrm{PCD}=$ protein coding; $\mathrm{TE}=$ transposable element. 